KRISTÍN INGVARSDÓTTIR

HÁSKÓLA ÍSLANDS

\title{
Ævintýraeyjurnar Japan og Ísland: Um Japansdvöl Nonna, 1937-1938
}

S eint á rithöfundarferli Jóns Sveinssonar, Nonna, rættist draumur hans um að heimsækja Japan. Jón lagði upp í heimsreisu einn síns liðs í ágúst 1936 nærri 79 ára gamall, sem var hár aldur á mælikvarða pess tíma. Hann var pá einn pekktasti Íslendingur samtímans og naut mikilla vinsælda á meginlandi Evrópu fyrir barnabækurnar um Nonna og Manna, sem alls voru pýddar á um 30 tungumál. ${ }^{1}$ Áfangastaðirnir voru fyrst og fremst tveir: fyrst Bandaríkin og síðan Japan. Jón kom til Japans vorið 1937 og dvaldist í eitt ár við hinn pekkta Sophia-háskóla í Tókýó, sem rekinn var af trúbræðrum hans í Jesúítareglunni. Jón skráđi ferðasögu sína og kom hún út á Íslandi í tveimur hlutum að honum látnum undir heitunum Ferð Nonna umbverfis jörðina (1955) og Nonni i Japan (1956). Í ferðasögunni segir frá Japansdvölinni á fjörlegan hátt, en hún er langt frá pví að teljast með pekktari eða vinsælli verkum höfundar. ${ }^{2}$ Japansdvölin er pó um margt merkileg heimild, par sem hún veitir innsýn í eina af fyrstu meiriháttar landkynningunum sem Íslandi hefur hlotnast í fjarlægum heimsálfum, enda bótt hún hafi alls ekki verið skipulögð sem slík. Einnig tengist hún með áhugaverðum hætti sögu Jésúítareglunnar og kapólskunnar í Japan á millistríðsárunum. Jón kom víða við meðan á dvölinni í Japan stód. Hann hélt 56 fyrirlestra vítt og breitt um landið, p.m.t. í virtustu

1 Gunnar F. Guðmundsson, Pater Jón Sveinsson: Nonni, bls. 7. Sjá einnig lista í dagbók Jóns yfir 27 tungumál sem Nonnabækurnar höfu verið pýddar á (dagbók 8+9, færsla 9. des. 1937), en fleiri pýðingar hafa bæst við síðar.

2 Sjá t.a.m. ritdóm um fyrri hluta ferðabókarinnar í Pjóơviljanum, par sem gagnrýnandi (B.B.) tekur fram að Jóni sé „nokkuð tekið að förlast, enda kominn yfir áttrætt“. „Nonni í Ameríku“, bls. 6. 
menntastofnun landsins, Keisaralega háskólanum í Tókýó; hann kom fram í útvarpi og prjár af bókum hans komu út á japönsku um petta leyti. Honum var sómi sýndur af bæði japönsku keisarafjölskyldunni og forsætisráðherra landsins; hann var aufúsugestur hjá sendiherrum, rithöfundum og ýmsu menntafólki og hundruð barna flykktust oft til að hlýða á fyrirlestra hans og upplestra. ${ }^{3}$ Аð auki var tî́ og umfangsmikil umfjöllun um Jón og Nonnabækur hans í japönskum dagblöðum og tímaritum meðan á dvölinni stóð, en markmiðið með ritun pessarar greinar er einmitt að kynna og greina pá fjölbreyttu umfjöllun. Greinarnar eru langflestar á japönsku og ekki hefur verið fjallað um efni peirra áđur, hvorki á Íslandi né í Japan, að örfáum greinum undanskildum.

Sagnfræðingurinn Gunnar F. Guðmundsson hefur ritað ítarlega ævisögu Jóns (2012) par sem Japansdvölinni eru gerð góð skil. Bókin byggist á umfangsmikilli rannsóknarvinnu á bæði íslenskum og erlendum frum- og eftirheimildum, en pó einungis að litlu leyti japönskum. Markmiðið með pessari grein er að varpa ljósi á Japansdvöl Jóns á grundvelli rannsóknar á japönskum heimildum frá peim tíma sem Jón dvaldist í Japan. Leitast verður við að svara hvar og með hvaða hætti fjallað var um rithöfundinn og verk hans í japönskum dagblöðum og tímaritum. Til grundvallar liggja heimildir, sem greinarhöfundur hefur aflað í japönskum skjalasöfnum og gagnagrunnum, ásamt japönskum heimildum á Nonnasafni Landsbókasafns. Með pví að rannsaka pessar heimildir bætist nýtt sjónarhorn við fyrri rannsóknir á Japansdvöl Jóns. Jafnframt verður lögð áhersla á að varpa ljósi á pær pjóðfélags- og trúarhræringar sem ruddu sér til rúms í Japan á fyrri hluta síðustu aldar og hafa vafalítið haft áhrif á pær viðtökur sem höfundurinn og verk hans fengu í Japan. Greinin er pannig byggð upp að hún hefst á stuttum inngangskafla, par sem rætt er um heimildir um viðfangsefnið og fyrri skrif um Japansdvöl Jóns. Аð öðru leyti skiptist greinin í tvo meginhluta. Í fyrri hlutanum er fjallað um stöðu Japans í alpjóðlegu samhengi á peim árum sem Jón kemur til Japans, sem og stöðu trúarbragða og Sophia-háskólans á fjórða áratugi sídustu aldar. Í seinni hlutanum er fjallað um pá mynd sem japanskar heimildir

3 Gunnar F. Guðmundsson, Pater Jón Sveinsson: Nonni, bls. 385-400. 
gefa af Japansdvöl Jóns og peim viðtökum sem hann hlaut í landinu.

\section{Heimildir um viðfangsefnið og fyrri skrif}

Líklega hefur Jóni Sveinssyni hvergi verið sýnd jafnmikil virðing og athygli og í Japan. Рað var alla vega upplifun hans sjálfs líkt og lesa má í bæði ferðabókinni, Nonni i Japan, og dagbókum Jóns. Sagnfræðingurinn Gunnar F. Guðmundsson tekur í sama streng í gagnmerkri ævisögu Jóns, Pater Jón Sveinsson: Nonni (2012). Japansdvöl Jóns hefur bó ekki hlotið pá athygli sem hún verðskuldar, og má e.t.v. segja að pað sama eigi við um allt ævistarf Jóns. Tvær greinargóðar eftirheimildir eru pó til um Japansdvölina. Sú fyrri er undirkafli um Nonna í Japan í áđurnefndri ævisögu Gunnars um Jón, en hún er byggð á umfangsmikilli rannsóknarvinnu á bæði íslenskum og erlendum frum- og eftirheimildum. Í bókinni er Japansdvölinni gerð afbragðsgóð skil og lesendur fá tækifæri til að kynnast bæði pví sem á daga Jóns drífur og hvernig hann hugsar og tjáir sig um dvölina í dagbókum sínum og bréfum til vina og ættingja. Hin heimildin er japönsk sýning um Nonna, Seinni ferð Nonna til Japans, sem var opnuð í Tókýó haustið 2008 í samstarfi Nonnahúss á Akureyri og Motokatsu Watanabe, fyrrverandi sendifulltrúa í sendiráði Japans á Íslandi. ${ }^{4}$ Watanabe, er lögfræðingur að mennt, en hann tók miklu ástfóstri við Nonna á meðan hann starfaði á Íslandi og fékk pví áorkað að sýning um Nonna var opnuð í Japan og að bókin Nonni og Manni og undursamlega devintýrið var endurútgefin í nýrri pýðingu hans sama ár. Sýningin byggist í grunninn á ferðasýningu sem Nonnahús á Akureyri gerði um Jón árið 2007 í tilefni af 150 ára fæðingarafmæli hans, en par við bætist efni sem Watanabe safnaði sérstaklega um Japansdvöl Jóns. ${ }^{5}$ Watanabe hefur tekið við-

4 Sýningin var haldin í Jiyu Gakuen menningarmiðstöđinni í Tókýó og hét á japönsku ハンニの70 年後の再訪日[Nonni no nanajūnengo no saihōnichi]. Sýningin er í íslenskum fjölmiðlum kölluð Seinni ferð Nonna til Japans, sjá t.d. grein með sama titil í Fréttablaðinu p. 19. sept. 2008, bls. 24.

5 Fjölmargir lögðu hönd á plóg bæði í Japan og á Íslandi til að gera sýninguna að veruleika, p.á m. Vináttufélag Íslands í Japan. Yukiko Koshizuka, fyrrverandi starfsmaður hjá japanska sendiráđinu, vann lengi að sýningunni og pýddi m.a. texta sýningarinnar yfir á japönsku. (Skv. tölvupósti frá Brynhildi Pétursdóttur, fyrrverandi safnstjóra Nonnahúss, júlí 2020. Brynhildur vann að sýningunni fyrir hönd safnsins og lét greinarhöfundi japönsku sýningarspjöldin í té.) 
töl við eldri Japani sem hlýddu á Jón sem börn, leitað að efni um Jón á skjalasöfnum ýmissa skóla sem Jón heimsótti og safnað umfjöllun um höfundinn í Japan. ${ }^{6}$ Aðeins lítill hluti af efninu er bó með í sjálfri sýningunni pannig að hún bætir litlu við rannsókn Gunnars F. Guðmundssonar hvað upplýsingar varðar. Sýningin hefur bó mikið gildi í japönsku samhengi par sem nafn Nonna var við pað að falla í gleymsku pegar Watanabe hóf kynningarátak sitt. ${ }^{7}$ Að lokum má nefna að greinarhöfundur birti yfirlitsgreinar um samskiptasögu Íslands og Japans í vor- og hausthefti Skirnis árið 2017 og í fyrri greininni sem fjallar um samskipti landanna fyrir seinni heimsstyrjöld er vikið stuttlega að Japansdvöl Jóns. ${ }^{8}$ Jafnframt ber að nefna bókina Nonni og Nonnabús (1993) eftir Jón Hjaltason, en mikið af myndum úr Japansferðinni prýða bókina. ${ }^{9}$ Með pessari grein gefst tækifæri til að fara nánar í saumana á Japansdvölinni, en hin mikla fjölmiðlaumfjöllun um höfundinn par í landi gefur vísbendingar um stöðu Jóns og Nonnabókanna í Japan; hvaða mynd var dregin upp af Jóni; hver markhópurinn var fyrir Nonnabækurnar og hverju Jón kaus sjálfur að koma á framfæri. Við rannsóknina hefur greinarhöfundur leitað fanga víða, m.a. í handritadeild aðalbókasafns Sophia-háskólans, St. Miki bókasafninu í Tókýó, sem rekið er af Jesúítareglunni, rafrænum leitargrunnum japanska landsbókasafnsins (j. Kokkai Toshokan) og Nonnasafni Landsbóksafns Íslands. Til grundvallar rannsókninni liggja u.p.b. 70 japanskar blaða- og tímaritsgreinar ${ }^{10}$ en pó er ekki hægt að útiloka að umfjöllun um Jón Sveinsson hafi birst víðar.

\footnotetext{
6 Viðtal greinarhöfundar við Watanabe í Tókýó, maí 2018.

7 Málping var haldið í tilefni af opnun sýningarinnar og Watanabe hélt fjölda erinda um Nonna í kjölfar hennar og endurútgáfu Nonnabókarinnar. Margir eldri Japanir muna enn eftir Nonna og Nonnabókunum að sögn Watanabe. (Skv. viðtali greinarhöfundar við Watanabe vorið 2018.) Mögulegt er að hluti af rannsóknarvinnu Watanabe sem hér er nefnd hafi farið fram eftir opnun sýningarinnar.

8 Kristín Ingvarsdóttir, „,,Frá Sóleyjum“: Upphaf samskipta Íslendinga og Japana 1904-1942“, sjá sérstaklega bls. 91-100, sem fjalla um Japansdvöl Jóns og íslenska trúboða í Japan fyrir seinni heimsstyrjöld.

9 Sjá sér í lagi myndaröð með skýringartextum á bls. 57-68.

10 Greinarnar birtust í Japan í tengslum við dvöl Jóns í landinu á árunum 1937-1938. Greinarnar eru almennt ekki nefndar í heimildalista nema að í pær sé vísað beint.
} 


\section{Japan á fjórða áratugi 20. aldar}

Í sögu Japans er árið 1930 pekkt sem upphafsár átakanlegs tímabils, sem sîðar hefur oft verið kallað „dimmi dalurinn“ af sagnfræðingum. Tímabilið spannar árin 1930 til 1945, en á pessum tíma tóku Japanir skarpa beygju frá alpjóðahyggju og lýðræðishyggju sem einkennt höfðu áratugina á undan. ${ }^{11}$ Í hverju fólst pessi mikla stefnubreyting Japana í kringum 1930 og hvaða áhrif hafði hún á japanskt samfélag? Óhætt er að fullyrða að Japan hafi verið á hraðri uppleið í alpjóðasamfélaginu við upphaf 20. aldar. Eftir að landið var opnað fyrir umheiminum árið 1853 lögðu Japanir alla áherslu á að nútímavæðast og iðnvæðast hratt og örugglega til að styrkja stöðu sína. Flest ríki Asíu lutu pá stjórn erlendra ríkja sem formlegar eða óformlegar nýlendur og Japanir vildu ekki lenda í sömu stöðu. Peir höfðu metnaðarfull áform fyrir landið og vildu frekar skipa sér í flokk með nýlenduherrum en að lenda undir hæl peirra. Japanir unnu stóra sigra á komandi árum og uppskáru bæði jákvæða athygli frá stórveldum pess tíma og landvinninga í Asíu. Árið 1895 tryggðu Japanir sér yfirráo yfir Taívan ${ }^{12}$ eftir sigur á Kínverjum; árið 1905 unnu Japanar sigur á Rússum eftir fræga sjóorrustu á Japanshafi og árið 1910 höfðu Japanir tryggt sér yfirráð yfir Kóreuskaganum. Tvíhliða og alpjóðlegir samningar frá pessum tíma sýna einnig glögglega sterka stöðu Japans. Árið 1902 gerði Japan tvíhliða samning við Bretland til að stemma stigu við vaxandi áhrifum Rússa í Austur-Asíu; Japan barðist með Bandamönnum í fyrri heimsstyrjöld og átti fulla aðild að Versalasamningnum, og á priðja áratugi 20. aldar átti Japan í tíoum samningaviðræðum við Bretland og Bandaríkin um valdajafnvægi stórveldanna priggja í sjóhernaði. Japanir höfðu sett sér pað markmið að skipa sér í hóp voldugustu ríkja heims og pað hafði peim tekist.

Straumhvörf urðu í utanríkisstefnu Japana um og eftir 1930 og рað var Kína sem var bitbeinið. Japanir höfðu sérstakan augastað á Mansjúríu, víđáttumiklu landflæmi í Austur-Kína, sem var u.p.b. fjórum sinnum stærra en Japan. Japanir höfðu smám saman aukið umsvif sín á svæðinu en í september árið 1931 hóf Kwantung-her

11 Dæmi um trausta heimild um utanríkismál Japans á 19. og 20. öld er Japan E The Wider World: From the Mid-Nineteenth Century to the Present eftir japanska sagnfræðinginn Akira Iriye.

12 Taívan var almennt kölluð Formósa á pessum tíma. 
Japana innrás í Mansjúríu. Innrásin var reyndar gerð án sampykkis ríkisstjórnarinnar í Tókýó en hún taldi sig ekki eiga annarra kosta völ en að spila með til að hylma yfir hve illa herinn lét að stjórn. Árið eftir gengu Japanir skrefi lengra með pví að lýsa yfir stofnun nýs ríkis á meginlandinu, Mansjúkúó, en engum duldist að Japanir réðu öllu á bak við tjöldin. Pjóðabandalagið fordæmdi framgöngu Japana, en viðbrögð peirra voru að ganga úr bandalaginu árið 1933. Japanir héldu áfram að stækka yfirráðasvæði sitt í Mansjúríu og sumarið 1937 braust út stríð milli Japans og Kína, sem lauk ekki fyrr en með uppgjöf Japana í seinni heimsstyrjöld. Strỉðið kostaði miklar fórnir fyrir bæði Japani og Kínverja, jafnt í efnahagslegu tilliti og í mannslífum talið. Striððið hafði jafnframt pær afleiðingar fyrir Japan að landið stóð einangrað í samfélagi ríkjanna og leitaði pví nýrra bandalaga: Japan gekk í Anti-Kómintern bandalagið með Pjóðverjum sî̉la árs 1936 og í Príveldabandalagið með fasistaríkjunum Pýskalandi og Ítalíu árið 1940. Pessar sviptingar áttu eftir að skipta miklu máli fyrir býsku jesúítana sem voru gestgjafar Jóns í Japansferðinni, líkt og nánar verður fjallað um síðar.

Pessi stefnubreyting hafði ekki aðeins áhrif á alpjóðasamskipti Japans heldur gjörbreyttist andrúmsloftið í japönsku samfélagi par sem herinn og hægriöfl í landinu náđu sterkum undirtökum. Árið 1930 varð Osachi Hamaguchi forsætisráðherra fyrir morðtilraun og sagan endurtók sig árið 1932 pegar Tsuyoshi Inukai forsætisráðherra var skotinn á heimili sínu. Í báđum tilvikum voru árásarmennirnir eldheitir hægri-öfgamenn. Í febrúar 1936 ríkti svo sannkallað ófremdarástand í Tókýó pegar hægri-öfgahópur innan japanska hersins gerði tilraun til valdaráns. Pótt tækist að lokum að kveða niður uppreisnina höfðu stjórnmálaflokkarnir og hin lýðræðislegu öfl í landinu beðið mikinn skaða og nokkrir af pekktustu stjórnmálamönnum landsins höfðu misst lífið. Рað var búið að sýna og sanna að „rangar“ skoðanir gátu auðveldlega kostað mannslíf. ${ }^{13}$ Hvernig má pað vera að herinn og öfgahópar sem tengdust honum hafi náð svo miklum ítökum á svo skömmum tíma? Ein af skýringunum er sú að herinn naut mikillar hylli almennings. Margir Japanir studdu út-

13 Sjá nánar um uppgang hersins og pólitísku morðin á fjórða áratugi síðustu aldar í: Bix, Herbert P., Hirohito and the Making of Modern Japan, bls. 205-305. Nánar um valdaránið 1936 á bls. 295-305. 
penslustefnu Japana í Kína, hvers markmið var m.a. að komast yfir nýjar jarðir og ræktarland fyrir ört vaxandi íbúafjölda í Japan, og í fjölmiðlum bárust tîðar fregnir af glæstum sigrum á meginlandinu. Dagblöđin áttu stóran pátt í að draga upp hvítpvegna mynd af hernaðarsigrum Japans í Kína, en pess ber að geta að Japan varð snemma öflugt fjölmiðlaveldi með áhrifamikil dagblöð og prentmiðla. Almenningur í Japan var sigurreifur og í pví andrúmslofti sem ríkti var ekkert umburðarlyndi fyrir gagnrýni á japanska herinn. Pað er við pessar aðstæður sem Jón Sveinsson kom til Japans í mars árið 1937 og í ævisögu hans kemur glöggt fram hvernig hann hreifst með sigurgleði Japana. Раð er að mörgu leyti skiljanlegt að gestur í landinu hafi hrifist með á sama hátt og Japanir sjálfir.

\section{Ríkisrekinn shintóismi og staða „innfluttra“ trúarbragða}

Líkt og fram kemur að ofan voru miklar sviptingar í japönsku samfélagi á fjórða áratug sî̉ustu aldar og áhrifin á trúarstarf í landinu voru einnig grîðarleg. En til pess að geta áttað okkur á stöðu kristinna manna í Japan á peim tíma sem Nonni dvaldi í Japan purfum við að hverfa nokkra áratugi aftur í tímann og skoða stöðu trúarbragðanna í sögulegu samhengi. Árið 1868 markar upphaf Meijiendurreisnarinnar (e. Meiji Restoration), sem var umfangsmikið pjóðarátak til að færa stjórn landsins í hendur keisarans, varpa japönsku samfélagi inn í nútímann og koma Japan á kortið sem jafningja Vesturveldanna. Japan hafði áður verið lénsveldi og Japanir höfðu í gegnum aldirnar fyrst og fremst kennt sig við sitt lén eða nánustu heimkynni, en nú purfti að byggja upp pjóðernisvitund peirra sem Japana. Á örfáum árum tókst Japönum að tryggja sig í sessi sem nútímaríki með her og almenna herskyldu, pjóðfána, pjóðsöng, stjórnarskrá, pjóðping og lýðræðislega kjörna ríkisstjórn. Og ekki leið á löngu áđur en Japanir færðu út kvíarnar með nýlendum líkt og fram hefur komið. Sú stórfellda endurskoðun á öllum samfélagslegum páttum sem átti sér stað í Meiji-endurreisninni markaði einnig nýja stefnu fyrir trúarbrögð í landinu og Meiji-stjórnarskráin, sem tók gildi árið 1889, tryggði pegnunum trúfrelsi, en pó með nokkrum 
skilyrðum. Grein 20 um trúfrelsi er svohljóðandi: „Japanskir pegnar skulu njóta trúfrelsis innan peirra marka sem lög og reglur leyfa og svo lengi sem pað stangast ekki á við skyldur peirra sem pegna. " ${ }^{14}$ Petta nýja ákvæði tryggði ákveðin grunnréttindi en með nýjum áherslum breyttist jafnvægið sem ríkt hafði milli helstu trúarbragða í landinu: búddisma, shintóisma og kristni. ${ }^{15}$

Staða kristninnar í Japan hafði lengi verið flókin og kristnir menn höfou víða mætt ofsóknum, en með Meiji-endurreisninni var kristni leyfó á ný í Japan eftir rúmlega tveggja alda bann. Kristnir menn voru fáir í Japan en kristnin festi sig engu að síður í sessi sem eitt af premur megin trúfélögunum. Рað var ekki fjöldi kristinna manna í Japan sem gaf kristninni pessa stöðu heldur má leiða líkur að pví að kristnin í Japan hafi notið góðs af styrkleika kristninnar á heimsvísu. ${ }^{16}$ Shintóismi er aldagömul pjóotrú upprunnin í Japan en búddisminn barst til Japans frá meginlandi Asíu á 6. öld. Í fleiri aldir höfðu Japanir iðkað bæði shintóisma og búddisma en með Meijiendurreisninni voru gerð skil á milli japanskra og „innfluttra“ hefða og veikti bað töluvert stöðu búddisma í landinu. Búddismi hafði verið í hávegum hafour í gamla sjógun-veldinu en átti ekki eins upp á pallborðið í hinu nýja Japan. ${ }^{17}$ Frá 1868 og til loka seinni heimsstyrjaldar var shintóismi aftur á móti kostaður af ríkinu og er á pessu tímabili jafnan kallað ríkis-shintó (e. state shinto). ${ }^{18}$ Shintó var kynnt sem frum-japönsk hefð, sem hafði verið með Japönum frá örófi alda og áhersla var lögð á tengslin milli shintóisma og japönsku keisarafjölskyldunnar. Framan af var lögð mikil áhersla á að shintóisminn væri ekki trúarbrögð og ætti pví erindi til allra Japana óháð trú en árið 1940 varð algjör stefnubreyting og shintó fékk enn mikilvægara hlutverk sem ríkistrú. Hér verður ekki farið í saumana á trúarbrögðunum sjálfum, eða hvort shintóismi sé í eðli sínu trúarbrögð yfirhöfuð, heldur er áherslan lögð á stöðu stóru trúsamfélaganna í jap-

14 de Bary, William, Gluck og Tiedemann, Sources of Japanese Tradition, bls. 78. Pýðing greinarhöfundar.

15 Lítið hefur verið skrifað um shintóisma á íslensku og pví ekki skýr málhefô til staðar. Í greininni er talað um shintóisma frekar en shintótrú. Ekki er heldur skýr málhefo varðandi japönsku helgidómana en almennt talað um búddahof (e. temple) og shintóhelgidóm (e. shrine).

16 Marius B. Jansen fjallar t.d. um hve mikill prýstingur var frá erlendum ríkjum að leyfa kristni í Japan og bæta stöðu kristinna í The Making of Modern Japan, bls. 463.

17 Hardacre, Helen, Shintō and the State, 1868-1988, bls. 5.

18 Sama heimild, bls. 4. 
önsku samfélagi fram á fjórða áratug 20. aldar og samband peirra við ríkisvaldið.

Meiji-stjórnarskráin stuðlaði að pví að stofna miðstýrt nútímaríki. Miðstýring á öllum sviðum var mikilvægt markmið í sjálfu sér og mótun japanskra pegna par engin undantekning. Helstu verkfærin sem ríkið hafði til að móta æsku landsins voru menntakerfið og herinn. Árið 1890 var gefin út keisaralega tilskipunin fyrir menntun (e. Imperial Rescript on Education) sem send var í alla skóla landsins ásamt ljósmynd af keisaranum. Öll japönsk skólabörn skyldu nú sýna keisaranum lotningu daglega og njóta menntunar í pjóðernislegum anda. Strax í kjölfarið spruttu upp ritdeilur milli kristinna manna og andstæðinga peirra um hvort kristnum mönnum og nemendum í kristnum skólum í Japan bæri að hneigja sig fyrir keisaranum. Gátu kristnir pjónað bæði guði sínum og hinum guðlega keisara eða var kristnin kannski í beinni mótsögn við keisaradýrkunina? Petta var háalvarlegt mál og allir helstu trúarbragða- og heimspekingar landsins tóku pátt í ritdeilu sem spannaði yfir tvö ár og fjölda miðla, bæði trúarlegra og veraldlegra. ${ }^{19}$

Pótt gengi á ýmsu varð yfirvöldum samt ljóst að öll trúarbrögðin höfðu hlutverki að gegna pegar m.a. menntun og almennt siðferði var annars vegar og yfirvöld ætluðust til að trúfélögin gerðu sitt til að stuðla að lögum og reglu í samfélaginu. Ríkið og trúfélög áttu nefnilega sameiginlega óvini, kommúnismann og hin svokölluðu „nýju trúarbrögð“ sem skutu upp kollinum á millistríðsárunum og löðuðu til sín milljónir fylgjenda. ${ }^{20}$ Ríkisvaldið efndi til nokkurra herferða gegn bessum nýju trúarhópum eftir 1920 pótt margir peirra væru jafnvel sprottnir af shintóisma. Hernaðurinn ágerðist á næstu árum en vorið 1937 - einmitt pegar Jón var nýkominn til Japans - markar páttaskil pegar kemur að trúarofsóknum í Japan. Ríkisvaldið réðst gegn nokkrum af stærstu hópunum, p.m.t. shintó-hópnum Hitonomichi Kyodan sem var bó ein af prettán shintó-reglum sem ríkið viðurkenndi. Vottar Jehóva í Japan hlutu sömu útreið 1938 og 1940. ${ }^{21}$ Öllum mátti pví vera ljóst að engin trúfélög gátu talist örugg og til-

19 Anderson, Emily. Christianity and Imperialism in Modern Japan: Empire for God, sjá sérstaklega kaflann „The Problem of Two Masters“, bls. 27-61.

20 Garon, Sheldon M., „State and Religion in Imperial Japan, 1912-1945“, sjá m.a. bls. 281-282.

21 Sama heimild, bls. 289-290. 
vistargrundvöllur peirra fólst í að storka ekki ríkisvaldinu á nokkurn hátt. Pegar Japanir voru komnir í allsherjarstríð með árásinni á Pearl Harbor 1941 var enn frekar hert á stýringu og eftirliti með trúarhópum í Japan.

Раð hefur verið algeng sögutúlkun að kristnir í Japan hafi verið mjög jaðarsettir á stríðsárunum sem iðkendur „erlendra trúarbragða“ og hafi pví átt lítinn pátt í að styðja og taka pátt í pví pjóðernis- og hernaðaræði sem gekk yfir Japan. Nýrri rannsóknir leggja aftur á móti áherslu á að stóru trúarhreyfingarnar hafi í mörgum tilvikum átt sameiginlegra hagsmuna að gæta innbyrðis - og með ríkinu, m.a. pegar kom að pví að hefta uppgang kommúnisma og hinna nýju trúfélaga sem „stálu“ iðkendum hinna hefobundnu stofnana. Nýrri rannsóknir leggja pannig áherslu á að pað hafi ekki bara verið hin ríkisvædda shintó-stofnun heldur trúfélögin öll sem hafi spilað eftir peim leikreglum sem voru settar og hafi öll átt hlutverki að gegna í uppgangi pjóðernishyggjunnar og hægrisveiflunnar í Japan. ${ }^{22}$ Pess ber einnig að geta að pað var mikill munur á pví hvernig ólíkir kristnir hópar og einstaklingar brugðust við pessum nýju áherslum og prýstingi frá bæði yfirvöldum og samfélaginu. Sumir aðhylltust friðarstefnu eða fannst pað guðlast að „dýrka“ keisarann líkt og til var ætlast, á meðan aðrir studdu útpenslustefnu japanska keisaraveldisins af heilum hug. ${ }^{23}$

\section{Sophia-háskólinn og línudans kristinna manna}

Eins og pekkt er á Íslandi gekk rithöfundurinn Jón Sveinsson í raðir jesúíta eftir margra ára nám og undirbúning við skóla og háskóla reglunnar vítt og breitt um Evrópu ${ }^{24}$. Jesúítarnir höfu í gegnum aldirnar byggt upp umfangsmikið net trúboða og starfsstöðva víða um heim og hvarvetna var mikil áhersla lögð á menntun og skólastarf. Рað var í gegnum pessa öflugu alpjóðlegu stofnun sem Jón Sveinsson ferðaðist víða um Evrópu sem nemandi, kennari og sî̉ar

\footnotetext{
22 Sjá umræðu hjá bæði Andersen og Garon í verkum peirra sem vitnað er í hér að ofan.

23 Detta er ein helsta niðurstaða Andersen í bókinni Christianity and Imperialism in Modern Japan, sem hér hefur verið vitnað í.

24 Gunnar F. Guðmundsson fjallar ítarlega um námsferil Jóns meðal jesúíta í ævisögunni Pater Jón Sveinsson: Nonni.
} 
rithöfundur. Undir lok ferilsins átti hann einnig pví láni að fagna að komast í heimsreisu á vegum Jesúítareglunnar, sem tók heil tvö ár með langri dvöl í bæði Bandaríkjunum og Japan. Ekki er alveg ljóst hvernig pað atvikaðist að Jón hélt til Asíu en hitt er ljóst að hann hafði alltaf langað til að komast til Japans og pað virðist hafa hentað Jesúítareglunni vel að slá tvær flugur í einu höggi með pví að kynna hinn heimsfræga rithöfund og verk hans, og styrkja starfsemi trúbræðranna í leiðinni. ${ }^{25}$ Pótt starfsemi jesúítanna væri umfangsmikil áttu peir pó víða í vök að verjast um pessar mundir. Lýðræðissinnar á Spáni höfðu t.a.m. gert allar eignir Jesúítareglunnar upptækar par í landi örfáum árum áour og próunin í Pýskalandi nasismans olli einnig áhyggjum. Jón vonaðist til að málin myndu leysast á farsælan hátt en að „óbreyttu vildi hann að Jesúítarnir hefðu hægt um sig og ögruðu ekki stjórnvöldum. Hann fylgdi að pví leyti stefnu æðsta manns reglunnar. “26

Jón kom til Japans siglandi frá Bandaríkjunum og gekk á land í Yokohoma pann 18. mars 1937. Gestgjafar hans og trúbræður í Jesúítareglunni við Sophia-háskólann í Tókýó tóku fagnandi á móti honum og par upphófst hið mikla ævintýri sem Japansdvölin var. Bókin Nonni í Japan kom út að Jóni látnum árið 1956 en verkið er að hluta til skáldskapur pannig að hér er ævisaga Nonna eftir Gunnar F. Guðmundsson fyrst og fremst höfð til hliðsjónar varðandi helstu staðreyndir ferðarinnar, enda byggist ævisagan á dagbókum og bréfasafni Jóns.

Sophia-háskólinn er nú einn af pekktustu einkaháskólum Japans með u.p.b. 11 púsund nemendur. Hann stendur miðsvæðis í Tókýó, á sama stað og pegar Jón dvaldist við háskólann. Mikil breyting hefur orðið á stærð og ásýnd háskólalóðarinnar en byggingin par sem ætlað er að Jón hafi búið stendur enn. ${ }^{27}$ Byggingin er eftir tékkneska arkitektinn Jan Letzel: ${ }^{28}$ hún er hvít, stílhrein og tignarleg og stendur í elsta kjarna háskólasvæðisins, ásamt gamla menningarhúsinu Kulturheim og gömlum japönskum garði frá Meiji-tímabilinu. Nokkrir

25 Sama heimild. Sjá nánar um tildrög ferðarinnar, bls. 366-368.

26 Sama heimild, bls. 386.

27 Viðtal greinarhöfundar við fulltrúa Jesúíta við Sophia-háskólann, 2018 og 2019.

28 Letzel teiknaði einnig eina pekktustu byggingu Japans, sem nú er pekkt sem byggingarrústin „Genbaku Domu“ eða „Atomic Dome“, sbr. „The Launching of a Small Residence Hall ...", bls. 4. 
jesúítar sem komnir eru á efri ár búa enn í húsinu en byggingin pykir ótraust og til stendur að rífa hana á næstu árum. ${ }^{29}$ Í skrifum Jóns kemur fram að hann bjó í herberginu par sem fyrrverandi forseti háskólans bjó áđur og Jón kunni vel að meta pann heiður sem honum var sýndur.

Pótt Sophia sé nú virtur og pekktur háskóli átti hann erfitt uppdráttar í fyrstu. Eins og áður sagði hafði kristni lengi verið bönnuð og mætti nokkurri tortryggni en auk pess áttu jesúítarnir víða í vök að verjast sem veikti fjárhagsstöðu reglunnar. Á hinn bóginn nutu jesúítar nokkurrar sérstöðu meðal kristinna trúfélaga í Japan par sem fyrsti trúboðinn sem kom til Japans, hinn pekkti Francis Xavier, sem kom til Japans árið 1549, tilheyrði einmitt Jesúítareglunni. ${ }^{30}$ Xavier hafði lýst yfir áhuga sínum á pví að stofna háskóla í Japan og árið 1906 gaf Píus páfi tíundi tilmæli um að stofnuð skyldi æðri menntastofnun jesúíta í Japan. Sophia-skólinn var settur á laggirnar árið 1911 og tveimur árum síðar fékk hann starfsleyfi sem háskóli með prjár deildir fyrir heimspeki, pýskar bókmenntir og viðskipti. ${ }^{31}$ Háskólinn heyrði undir hið pýska umdæmi Jesúítareglunnar og býska var notuð sem fyrsta mál við háskólann. Jesúítarnir fundu fyrir áhuga Japana á m.a. pýskri heimspeki og siðfræði og pegar háskólinn var opnaður reyndist einnig mikill áhugi á námi við hina nýju viðskiptadeild. $^{32}$

Fyrri heimsstyrjöldin (1914-1918) reyndist mikil áskorun fyrir háskólann. Japanir börðust gegn Pýskalandi í strỉðinu; nánast ómögulegt reyndist að manna stöður við háskólann vegna ferðatakmarkana og fjárhagsstaðan í Pýskalandi var slík að trúbræður peirra í pýsku höfuðstöðvunum voru engan veginn aflögufærir. ${ }^{33}$ Ekki tók betra við nokkrum árum sî̉ar pegar nýlega vígðar skólabyggingar háskólans, sem og aðrar eignir, stórskemmdust í Tókýó-jarðskjálftanum mikla árið 1923. Um svipað leyti geysaði óđaverðbólga í Pýskalandi og pví engrar aðstoðar að vænta paðan. ${ }^{34}$ Um 1930 hafði tekist að reisa nýja skólabyggingu og vorið 1932 var opnuð ný deild sem sérhæfði sig í

\footnotetext{
29 Viðtal við fulltrúa jesúíta við Sophia, 2018 og 2019.

30 „Xavier and Sophia University, No. 37“, bls. 1.

31 „History of Sophia University“.

32 Geppert, Theodor, The Early Years of Sophia University, bls. $12 \mathrm{og} 67$.

33 Sama heimild, bls. 70-74.

34 „History of Sophia University“.
} 
blaðamennsku. ${ }^{35}$ Ekki leið pó á löngu áđur en nýtt áfall reið yfir. Pann 5. maí 1932 átti sér stað hið svo kallaða „Yasukuni-atvik“ par sem Sophia-háskólinn var í brennidepli, en atvikið sýnir glögglega togstreituna milli ríkisins og trúarhópa, sem og viðkvæma stöðu kristinna manna og stofnana í Japan á fjórða áratugnum. Atvikið er oft nefnt 1 japönskum sagnfræðiritum sem dæmi um einmitt petta, en oútgefið handrit séra Theodors Gepperts um fyrstu ár Sophia-háskólans gefur góða innsýn í atburðarásina og er hún pví höfð til hliðsjónar. ${ }^{36}$ Ofurstinn sem bar ábyrgð á pjóðernislegri menntun við háskólann ákvað pennan dag að fara með hóp af nemendum skólans í Yasukuni-helgidóminn (j. Yasukuni Jinja, e. Yasukuni Shrine): einn pekktasta helgidóm shintóismans par sem japanskir hermenn sem látið hafa lífið fyrir föðurlandið eru heiðraðir. Markmið ferðarinnar var að votta hinum látnu virðingu með hinu formlega sampai, langri lotningarfullri hneigingu að shintó sið. Ekki vildi betur til en svo að prír af nemendunum neituðu að hneigja sig í helgidómnum og pegar farið var að spyrja út í atvikið kom í ljós að forseti háskólans, séra Hermann Hoffmann, hafði gefið pau tilmæli að sem kapólikkum bæri peim ekki að hylla látna forfeður og hermenn. Pessi viðhorf voru í samræmi við opinbera stefnu kapólsku kirkjunnar sem leit svo á að sampai-hneigingarnar væru trúarlegs eðlis og forfeðradýrkun falstrúarbrögð pannig að hneigingarnar væru allsendis óboðlegar kapólikkum. Hermálaráđuneytið brást við atvikinu á versta veg en menntamálaráđuneytið reyndi að miðla málum og gaf háskólanum formlega tilskipun pess efnis að sampai væri skylda fyrir alla nemendur en að hneigingin hefði aðeins pann tilgang að sýna fram á föðurlandsást og hollustu. Í október sama ár, pegar lausn virtist í sjónmáli, var upplýsingum um deiluna lekið í fjölmiðla. Háskólinn var harðlega gagnrýndur í fjölmiðlum fyrir andpjóðernisleg viðhorf og nokkrir miðlar fóru jafnvel fram á að kapólskir skólar í landinu yrðu jafnaðir við jörðu. Eftir mikið póf náđust sættir milli yfirvalda og háskólans en með pví ófrávíkjanlega skilyrði að kennslan yrði framvegis í sönnum japönskum pjóðræknislegum anda. Dagbækur Nonna frá Japan gefa

\footnotetext{
35 Sophia 100 years.

36 Geppert, Theodor, The Early Years of Sophia University, bls. 77-85. Sjá einnig greinina „The 1932 Yasukuni Shrine Incident, No. 40“ úr 100 ára afmælissmáritum Sophia-háskólans. Lýsing Gepperts er ítarlegri og er pví stuðst við hana.
} 
sterklega til kynna að háskólinn hafi staðið við loforðið, enda verður hann oft vitni að og pátttakandi í athöfnum par sem pjóðernishyggjan er allsráđandi og hrífst af pví sem fyrir augu ber. ${ }^{37}$ Háskólinn tók jafnframt túlkun menntamálaráđuneytisins á sampai góða og gilda (b.e. að hún væri ekki trúarlegs eðlis) og árið 1936 staðfesti Píus páfi tíundi pessa túlkun. Pótt sættir tækjust í málinu hafði orðspor háskólans pó beðið mikla hnekki. Nemendum fækkaði fyrstu árin á eftir og árið 1934 náði skólinn t.a.m. ekki að fylla nema um fimmtung peirra rúmlega 1000 skólaplássa sem hafði verið gert ráð fyrir. Fyrir ungan einkarekinn háskóla hefur petta ástand verið mikið áfall, ekki síst fjárhagslega. $^{38}$ Verðandi forseti háskólans, Hermann Heuvers, og samstarfsmaður heimsóttu menntaskóla vítt og breitt til að kynna háskólann í peirri von að fjölga mætti nemendum. Ætla má að stjórnendur Sophia-háskólans og annarra kristinna menntastofnana hafi haldið sig vel innan leyfilegra marka japanskra stjórnvalda eftir pessa afdrifaríku uppákomu. Mikilvægt er að skoða heimsókn Jóns Sveinssonar í pessu ljósi til að skilja betur annars vegar (ógagnrýnin) viðhorf gestgjafanna og Jóns til samfélagspróunar í Japan og hins vegar hvernig dvöl Jóns nýttist gestgjöfunum og mögulega öðrum kristnum hreyfingum í Japan í víðara samhengi.

\section{Nonni í Japan 1937-1938: Heimsfrægur rithöfundur á ferð}

Pegar Jón lagði af stað í heimsreisuna voru viðsjárverðir tímar í Evrópu og ekki var staðan mikið betri í Japan par sem landið hafði sagt sig úr Pjóðabandalaginu (e. League of Nations) árið 1933; Japanir höfðu átt í strîđi við Kínverja sîđan 1931 og pjóðernissinnaður öfgahópur innan hersins hafði reynt valdarán í Tókýó í upphafi árs 1936. Japanir og Pjóðverjar gengu jafnframt í bandalag haustið 1936. Jón var nýstiginn upp úr alvarlegum veikindum og pað vekur pví óneitanlega

37 Sjá t.d. dagbókarfærslu (dagbók merkt 8+9) par sem Jón er fullur hrifningar eftir að hafa tekið pátt í formlegri athöfn við háskólann par sem ný ljósmynd af keisaranum er afhjúpuð. Jóni verður líka tíðrætt í japönskum miðlum og bókinni Nonni í Japan um hátíðlegar kveðjuathafnir fyrir nemendur skólans sem hafa verið kvaddir til herskyldu.

38 Jóni varð fljótt ljóst hve illa statt trúboð jesúítanna var í Japan og að „hann yrði að gefa pví eitthvert fé, pó að ekki væri nema tvö eða prjú hundruð dollara fyrst um sinn“. Gunnar F. Guðmundsson, Pater Jón Sveinsson: Nonni, bls. 387. 
spurningar hvers vegna hann hélt ótrauður til Japans prátt fyrir ástandið sem par ríkti, og jafnframt hvernig vera megi að hann hafi haft svo eindregna jákvæða mynd af Japan og Japönum á sama tíma og umfjöllun um Japan hefur vafalítið verið lituð dökkum litum í heimspressunni.

Hvað sem allri gagnrýni leið var Japan sannkallað ævintýraland í augum Jóns og mögulega hefur honum hvergi verið jafn vel tekið og í Japan. Pað var alla vega upplifun hans sjálfs og hin umfangsmikla umfjöllun um Jón og Nonnabækurnar í Japan rennir stoðum undir pá upplifun hans. Tugir greina um Nonna birtust í japönskum prentmiðlum og náði yfir fjölda ólíkra miðla. Pess er vert að geta að útgáfustarfsemi var mjög lífleg í Japan á pessum árum (líkt og nú), enda læsi orðið næstum 90\% meðal fullorðinna um 1930 með innleiðingu skólaskyldu í kjölfar Meiji-endurreisnarinnar. ${ }^{39}$ Bókmenntir frá pessum tíma hafa pó oft verið afskrifaðar í seinni tîđ hvað varðar listrænt gildi og boðskap par sem ritskoðun varð sífellt meira áberandi eftir pví sem leið á stríðsrekstur Japana. Að lokum var allt prentað efni ítarlega ritskoðað, stundum svo kyrfilega að höfundar pekktu vart eigin texta eftir meðferðina. ${ }^{40}$

Pegar Jón kom til Japans var honum ljóst að til stóð að kynna hann og verk hans, og fyrstu greinarnar um hann birtust jafnvel ádur en hann kom til landsins. Mikilvægt er að skoða betur nokkra af peim lykileinstaklingum sem tóku á móti Jóni til að glöggva sig á bakgrunni peirra og tengingum við útgáfuheiminn í Japan. Strax á hafnarbakkanum hitti Jón Pjóðverjann Rupert Eberle. Hann „hafði áđur starfað hjá Herder í Freiburg og rak sîđar forlag og bókaverslun í Japan, áđur en hann varð lektor við háskólann. Hann var pví öllum hnútum kunnugur pegar kom að pví að kynna og gefa út Nonnabækur í Japan““41 Greinarhöfundi hefur ekki tekist að finna nánari upplýsingar um Eberle en ítarlegar verður fjallað um japanskar útgáfur á bókum Nonna hér á eftir. Helsti gestgjafi Jóns í Japan var forseti Sophia-háskólans, Hermann Heuvers. Eins og fram kemur í Nonni í Japan og ævisögu Jóns ${ }^{42}$ fylgdi Heuvers Jóni og túlkaði fyrir

39 Jansen, Marius B., The Making of Modern Japan, bls. 570.

40 Kawana, Sari., ,Reading Beyond the Lines ...", bls. 154.

41 Gunnar F. Guðmundsson, Pater Jón Sveinsson: Nonni, bls. 387.

42 Sama heimild. 
hann á mikilvægum samkomum og var honum til halds og trausts í gegnum annasama fyrirlestrar- og samkvæmisdagskrá. Ætla má að Heuvers hafi búið yfir umfangsmiklu tengslaneti sem gagnaðist við að koma Jóni á framfæri en eins og áður hefur komið fram hafði háskólinn frá upphafi kennt pýskar bókmenntir og var einnig meðal fárra háskóla í Japan sem bauð upp á sérhæft og faglegt nám í blaðamennsku. ${ }^{43}$ Háskólinn rak einnig dagheimili og menntaskóla, og ljóst er að háskólinn var vel tengdur öđrum kapólskum skólum, sem og almennum barnaskólum. Síðast en ekki síst ber að nefna Japanann Fukuo Kishibe en í Nonni í Japan er hann kynntur sem ,japanskur H. C. Andersen“, „frægur maður“ sem talinn er „mesta ævintýraskáld, sem nú er uppi í Japan“. ${ }^{44}$ Mikill vinskapur tókst með Jóni og Kishibe pótt peir virðist ekki hafa talað saman nema í gegnum túlk, og Jóni verður mjög tîðrætt um Kishibe í ferðabókinni. Er pað ekki að undra par sem sá síðarnefndi vann ötullega að pví að koma Jóni á framfæri, ekki aðeins í prentmiðlum eins og fjallað verður um; heldur einnig í m.a. útvarpspættinum sem áður var getið og stærstu barnasamkomunum sem Jón tók pátt í meðan á Japansdvölinni stóð. Töluvert er til af japönskum heimildum sem styðja pessar lýsingar á Kishibe. Í fjölmiðlum er hann jafnan kynntur til sögunnar sem einn fremsti sagnameistari landsins; hann var kosinn í borgarstjórn fyrir sinn borgarhluta í Tókýó (Kanda) sem óháđur frambjóðandi til að vinna að málefnum barna; hann átti sæti í fjölda nefnda og ráða um uppeldis-, velferðar-, lista- og menningarmál; og var auk pess stjórnandi dagheimilis og menntaskóla í borginni. ${ }^{45}$ Аð auki kemur fram að Kishibe var í miklum metum hjá keisarafjölskyldunni og skemmti m.a. dætrum keisarahjónanna og náskyldum prinsum og prinsessum í afmælum og við önnur tilefni. ${ }^{46}$ Í blaðagrein um Kishibe frá 1933, sem skrifuð var í tilefni af 61 árs afmæli hans, segir: „Kishibe San er í dag pekktur af milljónum barna í Japan og jafnvel enn fleiri fullorðnum sem fremsti ævintýra-sögumaður pjóðarinnar. ${ }^{\text {“’7 }}$ Óhætt er að

43 Geppert, Theodor, The Early Years of Sophia University, bls. 77.

44 Jón Sveinsson, Nonni í Japan, bls. 166-176. Í bókinni er japanski skáldbróðirinn iðulega kallaður aðeins eftirnafninu Kischibe en rétt stafsett og fullt nafn er Fukuo Kishibe (j. 岸邊福雄).

45 Detta kemur m.a. fram í ýmsum greinum um Kishibe sem birtust í japanska dagblaðinu Japan Times á fyrri hluta 20. aldar.

46 „Mr. Kishibe’s Birthday“, bls. 8.

47 Sama heimild. 
fullyrða að Kishibe hafi verið vel tengdur meðal mennta- og menningarfrömuða og gegnt lykilhlutverki pegar kom að pví að kynna Jón í Japan eins og nánar verður fjallað um hér á eftir.

Umfjöllun um Jón og Nonnabækurnar í japönskum heimildum mætti flokka og greina eftir efni eða tegundum miðla og er seinni lausnin valin hér. Umfjölluninni má gróflega skipta í eftirfarandi flokka:

\section{Dagblöð}

2. Kapólsk blöð og tímarit

3. Tímarit fyrir börn og ungmenni

4. Fagtímarit um barnabókmenntir og menntun barna

5. Nonnabækurnar sjálfar

\section{Dagblöd: Heimfragur rithöfundur á ferð}

Í bókinni Nonni í Japan setur Jón lesendur sína vel inn í dagblaðaútgáfu í landinu með nokkurra sîđna umfjöllun og svo lygilegar finnast honum staðhæfingarnar um að t.d. stórblaðið Asabi Shimbun seljist í alls premur milljónum eintaka á dag að hann spyr ítrekað til að sannreyna tölurnar. Jón lýkur umfjölluninni með eftirfarandi:

Nú var mér ljóst af öllu pví, sem Heuvers forstjóri hafði sagt mér, að stórblöðin höfðu ekki aðeins blaðamennskuna á valdi sínu, heldur pjóðina alla á vissan hátt. Hér var um stórveldi að ræða, ríki í ríkinu. Petta stórveldi var veldi dagblaðanna, „Pressan“, sem svo er nefnd á mörgum málum. ${ }^{48}$

Pessi lýsing er alls ekki fjarri lagi og pað er skiljanlegt að Jón hafi sérstakan áhuga á stærstu fjölmiðlum landsins par sem umfjöllun um hann birtist í nokkrum peirra. Óhætt er að fullyrða að umfjöllunin hefur haft mikið að segja fyrir orðspor Jóns í Japan í krafti útbreiðslu miðlanna og peirrar virðingar sem peir nutu. Í greinunum er fyrst og fremst dregin upp mynd af heimspekktum rithöfundi og heimshornaflakkara, sem alltaf er kenndur við Ísland frekar en hin pekktu Evrópulönd par sem hann hafði átt samastað í áratugi. Ein lengsta

48 Jón Sveinsson, Nonni íJapan, bls. 111. 


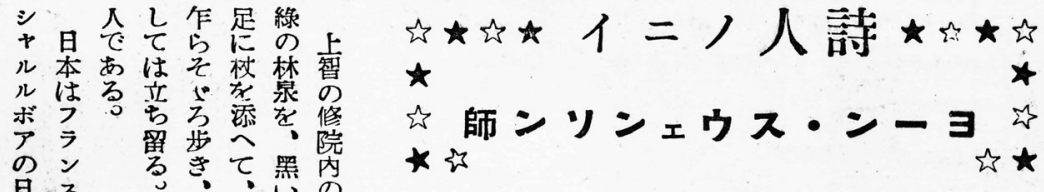

日 日

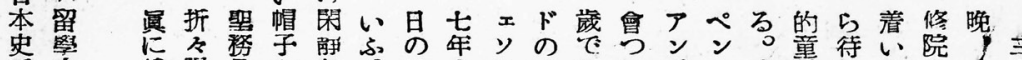

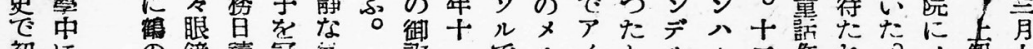

初に の镜禱冠垖

め瀷㮈ををり日

でなは誦愳。

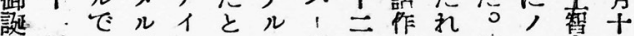
生月ードスいセゲの家た昨二太㤂

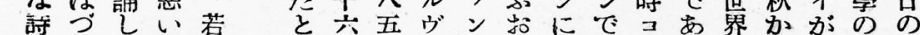
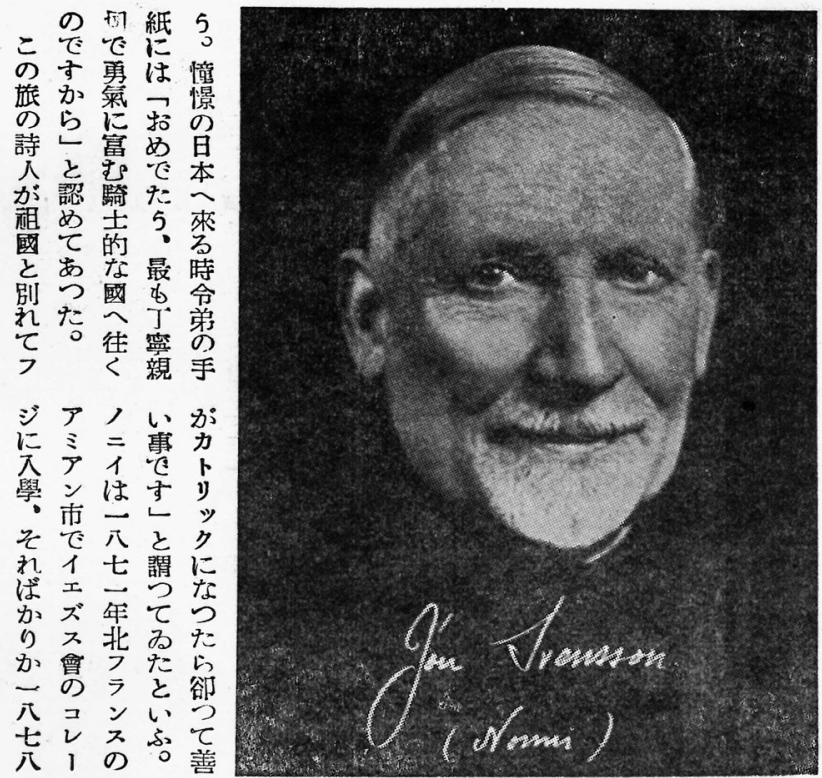

はでのひつ ど步勝偶た なな范忽 にか管露 ち 有一言戰日 頂た者爭条 天 に日樣始い

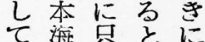
了海只空に 戰入 然 た勝 叫旦て ら報几本了 のど樣で ラ

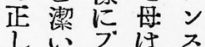
、敬口他 事虔 テの 留 灰な スア學 知知 夕 1 乙 つ識ンスた て人トラの 范ででンは りカあだ+

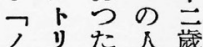
ニ け々な

るをのれ、槙ら地、健验けし著達イのンののコス作

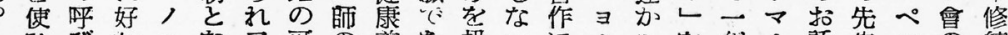
ひびがなア可の美あ披いに、に什１話生ンの練

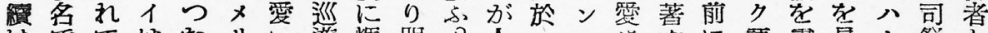

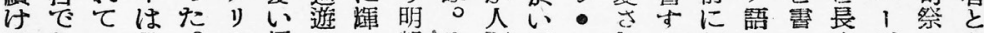

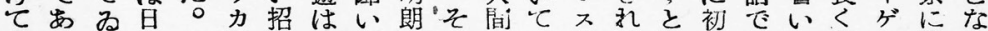

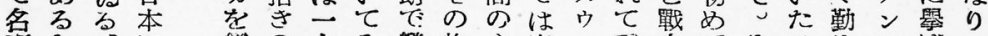

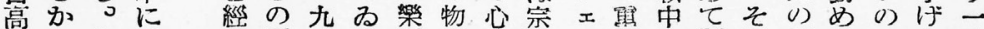

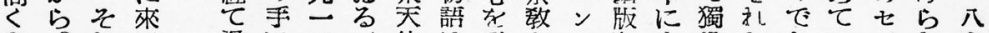

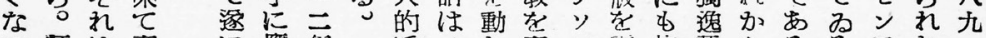
つ師は直に鹰焦 たは甘岕今藏來 のこがな 度て碩 で愛じの始州 あ名撫壬來め各

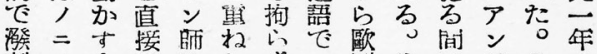

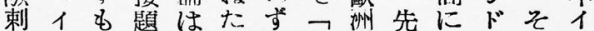

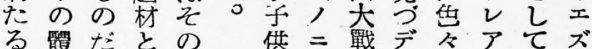

Dæmi um umfjöllun um Jón í Japan. Greinin er ein af mörgum frá Japan sem varðveitt er í Nonnasafni Landsbókasafns. Mynd: Greinarhöfundur, 2020. 
umfjöllunin birtist í dagblaðinu Japan Advertiser pann 21. mars 1937 við komuna til landsins og var pýðing á greininni birt í heild sinni í Lesbók Morgunblađins síđar á árinu. ${ }^{49}$ Jón er sagður pekktur í Evrópu sem „H. C. Andersen samtímans“ og „1́ New York sem Mark Twain“ og bækur hans eru sagðar hafa selst í yfir sex milljónum eintaka á fjölda tungumála. ${ }^{50}$ Í greininni er jafnframt farið lauslega yfir ævisögu og rithöfundarferil Jóns, sem og bakgrunn hans sem jesúíta. Ekki hefði verið hægt að hugsa sér betri kynningu og ljóst er að greinin hefur verið nýtt einmitt sem slík, en hún er varðveitt í heild sinni sem A4 dreifibréf í Nonnasafni Landsbókasafns. ${ }^{51}$ Japan Advertiser var sjálfstætt enskumælandi dagblað í eigu Bandaríkjamanns: Upplagið var ekki stórt en blaðið hafði sterka stöðu meðal alpjóðlega samfélagsins í Japan. ${ }^{52}$

Allt annað átti við um stórveldið Asabi Shimbun sem birti áhugaverða umfjöllun og greinaröð eftir Jón. Hér var um dagblað að ræða sem seldist í milljónum eintaka daglega um allt land (morgun- og kvöldútgáfa) og var alfarið gefið út á japönsku. Dagbókarfærsla Jóns ${ }^{33}$ bendir til pess að Asabi-dagblaðið hafi falast eftir að sitja eitt að blaðaumfjöllun um Jón og myndi pað skýra hvers vegna sjö góðar greinar um eða eftir Nonna birtust í Asashi Shimbun meðan á dvölinni stóð, en engin umfjöllun virðist hafa birst hjá t.a.m. keppinautnum Yomiuri Shimbun. ${ }^{54}$ Fyrst birtust tvær myndarlegar greinar til að kynna hinn pekkta höfund, daginn eftir komuna til landsins og svo viku sî̉ar, en seinni greinin er skrifuð til japanskra barna og birtist í sérstökum barnadálki. Tæpum mánuði síðar birtast svo greinar prjá daga í röð undir titlinum „Nihon no insho“ sem pýða mætti „Sýn mín á Japan“. Asahi vildi greinilega njóta gests auga hins reynda

49 „Nonni í Japan“, bls. 350.

50 Ekki er vitað með vissu hve mörg eintök seldust af Nonna-bókunum á heimsvísu en Brynhildur Pétursdóttir, fyrrverandi safnstjóri Nonnahúss, telur tölurnar stórlega ýktar eftir samtöl sín við aðra sérfræðinga (skv. tölvupósti til greinarhöfundar, sumar 2020).

51 Nonnasafn, Landsbókasafn, „Ýmis gögn, Japan“.

52 Stutt grein um komu Jóns til landsins birtist einnig í dagblaðinu The Japan Times p. 23. mars 1937. Greinin birtist í fasta dálkinum Art-Music-Letters, en greinin er mun styttri og lágstemmdari en umfjöllun Japan Advertiser. Tilkynningar birtust reglulega í blaðinu til að vekja athygli á fyrirlestrum Jóns á ensku og lítill kveðjudálkur tilkynnti að lokum um brottför Jóns.

53 Dagbækur II. Bindi, bók 8+9.

54 Greinarhöfundur hefur gert ítarlega leit að greinum um Jón Sveinsson og Nonnabækurnar í rafrænum grunnum bæði Asahi Shimbun og Yomiuri Shimbun. Mögulega leynast fleiri greinar pótt pað verði að teljast ólíklegt. 
heimshornaflakkara og pað fórst Jóni vel úr hendi. Greinarnar eru fullar af kímni; Jón gerir góðlátlegt grín að sjálfum sér og pað má ímynda sér að foreldrar hafi lesið greinarnar fyrir börn sín. Hann lýsir pví t.d. hvernig hann velti fyrir sér hvers vegna svo margir Japanir gengju með grímu fyrir vitunum ${ }^{55}$ og kemur með spaugilegar tilgátur:

Degar ég gekk um Tókýó, undraði ég mig á pví, að margt fólk var með grímur fyrir andlitinu. Hvað í veröldinni skyldi vera að. Ég velti pví fyrir mér hvort pað hefði verið í nefaðgerð. Petta flaug mér í hug vegna pess að fyrsta manneskjan sem ég sá hafði verið frekar illúðleg, hann gæti hafa lent í slagsmálum og fengið högg í andlitið. Næsta manneskjan sem ég sá var hins vegar fínn herramaður sem virtist ekki líklegur til að lenda í áflogum. Ég var ráðvilltur. Og eftir að hafa séð svo marga með grímur, var ég farinn að halda að parna gæti verið á ferðinni leynilegt grímufélag. Mér að óvörum, voru konur hins vegar líka með grímur, og pað sem verra var skrítnar svartar grímur. Ef konur purftu nauðsynlega að vera með grímur, hefði mér pótt hæfa betur að pær væru með fallegri grímur með útsaumuðum árstíðarbundnum blómum, til dæmis rós eða eitthvað í peim dúr. ${ }^{56}$

Tveimur dögum sîðar skrifar hann um erfiðleikana við að venjast japönskum siðum og matarvenjum, og pá sér í lagi baráttu sína við punnu japönsku zabuton-motturnar sem Japanir nota pegar peir sitja á gólfinu, sem var og er almenn hefð.57

Ég skimaði um herbergið í leit að stólum, en peir voru ekki par. Sîðan bauð fólk mér Zabuton og sagði mér að setjast. Í fyrstu kraup ég á mottuna hikandi. Á meðan vinir mínir studdu mig frá báðum hliðum, reyndi ég að setjast rólega niður. En hnén á mér létu ekki að vilja mínum. Og ég var við раð аð detta. Af pessum sökum staflaði fólkið fjórum Zabuton mottum hverri ofan á aðra. Síðan settist ég ofan á staflann eins og

55 Grímurnar voru fyrst og fremst notaðar sem sóttvarnargrímur eins og tîðkast í dag en pær hafa lengi verið útbreiddar í Japan.

56 Jón Sveinsson, „Nippon no inshō (1)“, bls. 7. Pýðing greinarhöfundar.

57 Í Japan tíðkast að sitja á hnjánum eða með krosslagða fæutur á einni zabuton-mottu og Japönum hefur eflaust fundist tilhugsunin skondin um útlendinginn sem reynir að hlaða peim saman til að búa sér til sæti. 
konungur. En hæðin var ekki enn nægileg til að pað færi vel um mig. Pannig að fólkið staflaði fjórum Zabuton mottum til viðbótar ofan á. Með pessu móti gat ég loks matast. Næsta vandamál voru prjónarnir. Ég tók pá tökum og hermdi eftir hinu fólkinu en maturinn slapp milli prjónanna. Pá greip ég til pess ráđs að halda prjónunum saman og nota eins og skeið til að færa matinn að munninum. [...] Á borðinu var bara framandlegur matur. Mér fannst sumt gott en annað var ég hreinlega ekki viss um hvort bragðaðist vel eða illa. ${ }^{58}$

Jón segir líka frá fyrsta jarðskjálftanum sem hann upplifði á ævi sinni, sem hann tengir að sjálfsögðu við Ísland; undrun sína og aðdáun yfir pví að kynnast japönskum fræðimanni og nemendum hans sem lögðu stund á íslensku og Íslendingasögurnar við Keisaralega háskólann í Tókýóog og svo mætti lengi telja. En hann fjallar líka um alvarlegri efni og í kveðjugreininni sem hann skrifar fyrir brottförina gerir hann föðurlandsást Japana að aðalviðfangsefni. Par lýsir hann hugprýði eins háskólanemanna pegar hann var kvaddur í herinn en ungi maðurinn segist ekki óttast dauðann og gefi glaður líf sitt fyrir föðurland sitt. Greinin lýsir bæði trega og aðdáun og má kannski lesa sem uppörvun og hvatningu til Japana í stríðinu. Greinin er í fullu samræmi við dagbækur Jóns og líklega hefur ekki purft neina ritskoðun frá gestgjöfunum við Sophia-háskólann eða yfirvöldum til að ná fram pessum hughrifum eða boðskap. Jón lýsir reyndar hvernig textar hans fyrir Asabi Shimbun hafi verið vandlega lesnir og býddir af kollegum Jóns við Sophia-háskólann, og pýðingarnar síðan „burstaðar, pvegnar og fægðar“ fyrir birtingu hjá Asabi en óljóst er hvort eiginleg ritskoðun af hálfu stjórnvalda hafi átt sér stað. ${ }^{60}$

Á sama hátt og umfjöllunin sem birtist m.a. um Jón í The New York Times í Bandaríkjunum og setti Jón á ákveðinn „stall“, var umfjöllunin um Jón í stærstu og virtustu dagblöðum í Japan í upphafi ferðarinnar til að greiða fyrir annarri umfjöllun sem á eftir kom. Jákvæð og umfangsmikil umfjöllun um höfundinn Jón og söguper-

\footnotetext{
58 Jón Sveinsson, „Nippon no insho (3)“, bls. 7. Pýðing greinarhöfundar.

59 Sjá nánar um íslenskunám og áhuga á Íslendingasögum í Kristín Ingvarsdóttir, „Frá Sóleyjum“ og „Samskipti Íslands og Japans“.

60 Gunnar F. Guðmundsson, Pater Jón Sveinsson: Nonni, bls. 389.
} 
sónuna Nonna styrkti pá ímynd að hér væri stórmerkilegur höfundur á heimsmælikvarða á ferð. Jón er jafnan kenndur við hið framandi Ísland og í skrifum hans má vart á milli sjá hvort hrifning hans er meiri á Japan eða Íslandi.

\subsection{Kapólsk blöð og tímarit: Fyrirmynd í trúnni}

Pað er ekki ofsögum sagt að Jón birtist sem stjarna í öllum helstu miðlum kapólsku kirkjunnar í Japan. Рað blasir við að hann er einn af peirra mönnum og við kynnumst trúmanninum og sagnameistaranum Nonna. Trúarleg köllun og upplifun er áberandi í allri umfjöllun; ævintýri og sögur Jóns fá að njóta sín til hins ýtrasta en frásagnir af Íslandi eru líka vinsælt umfjöllunarefni. Kapólikkar voru ekki margir í Japan á pessum árum (ekki frekar en nú) en hér hefur vafalítið verið um mikilvægan markhóp að ræða fyrir Nonnabækurnar. Beinar auglýsingar á Nonnabókunum fyrir jól og áramót eru áberandi í pessum tímaritum en pær sjást ekki í ödru samhengi. Helstu blöðin voru Nippon Katorikku Shimbun (Fréttablað kabólikka í Japan), Koe/Vox Catbolica (Rödd kapólskunnar) og Umi no Hoshi (Stella Maris). Svo virðist sem ein útgáfa, Miðstöð kapólskrar útgáfu, hafi staðið að útgáfu blaðanna og að miðstöðin hafi verið nátengd hinu kapólska biskuparáđi í Japan. ${ }^{61}$ Blöđin voru pví ekki sérstaklega tengd Jesúítareglunni og miðluðu fréttum almennt til kapólska samfélagsins sem dreift var um Japan. ${ }^{62}$ Heuvers, forseti Sophia-háskólans, og lykilmenn innan Jesúitatrúboðsins hafa vafalítið verið í góðri aðstöðu til að koma Jóni á framfæri og líklega hefur einnig verið eftirspurn eftir efni um Jón ef marka má pær miklu vinsældir sem fyrirlestrar hans nutu í Japan.

Fréttablað kapólikka kom út vikulega á sunnudögum en Vox Catbolica og Umi no Hoshi komu út mánaðarlega í tímaritsformi. Fyrra tímaritið miðaðist fyrst og fremst við fullorðna eða fjölskyldur og pað sî̉arnefnda við unga lesendur. Hér vekur fyrst og fremst athygli hve fyrirferðarmikil umfjöllunin um Jón og Nonnabækurnar er, sérstak-

61 Miðstöð kapólskrar útgáfu hét カトリック中央出版部 (Katorikku Chuo Shuppan-bu) og Kapólska biskuparádið hét カトリック中央協議会 (Katorikku Chuo Kyogikai), á ensku Bishops' Conference of Japan.

62 Skv. tölvupósti frá fulltrúa Jesúítareglunnar við Sophia-háskólann, sumar 2020.

34 Milli mála 12/2020

10.33112/millimala.12.1 
lega í mánaðartímaritinu Vox Catholica par sem Jón/Nonni er áberandi í næstum hverju einasta hefti meðan á Japansdvölinni stóð. Hér kennir ýmissa grasa: Birtar eru myndir af Jóni með ýmsum gestum háskólans eða frá fyrirlestrum hans; Jón er fenginn til að segja frá ýmsu sem á daga hans hefur drifið um ævina og stundum eru sögurnar pað sem kalla mætti „sögur af frægu fólki“. Pannig er fjallað um hvert Jón fer og hvern hann hittir, og greint frá ýmsum smáatvikum sem aðeins eru áhugaverð pegar pekktur einstaklingur á í hlut. Jafnframt birtist frásögn af ferð Jóns á hestbaki í kringum Ísland sem raðsaga í premur hlutum og saga kölluð Ævintýri á sjó, sem byggð er á Ævintýri Nonna og Manna, birtist einnig sem raðsaga. Stórar andlitsmyndir af Jóni birtast oft með greinum um eða eftir hann enda pótt lítið sé alla jafna af ljósmyndum í tímaritinu. Margar greinar birtast einnig í fréttablaðinu og í Umi no Hoshi en virðast ekki jafn tîđar og í Vox Catholica. Рað er pví ekki að undra að Japanir á ýmsum aldri kannist við Jón og gefi sig oft á tal við hann á mannamótum. Áskrifendum pessara tímarita hefur væntanlega liðið eins og peir pekktu manninn eftir svo tî̉ar fréttir af honum og pað er erfitt að ímynda sér að Japansdvöl Jóns hafi farið fram hjá neinum í hinu fámenna samfélagi kapólskra í Japan.

\subsection{Tímarit fyrir börn og ungmenni: Sagnameistarinn}

Í pessum flokki eru fallega skreyttar myndabækur og barnatímarit í háum gæðum, enda um að ræða pekktar útgáfur sem nutu mikilla vinsælda í Japan á millistrîđsárunum. Greinarhöfundur hefur fyrst og fremst kannað pau tímarit sem finnast í Nonnasafni Landsbókasafns en pað eru tímarit sem Jón flutti með sér heim til Evrópu. Ekki hefur enn gefist tóm til að leita að fleiri ritum af pessu tagi í Japan og pví er ekki útilokað að umfjöllun kunni að leynast í fleiri ritum. Líklegt er að Jón hafi tekið einmitt pessi rit með sér vegna pess að mikið var í tímaritin lagt og vegna pess að hann hafi orðið pess vís að pau áttu vinsældum að fagna í Japan. ${ }^{63}$ Í pessum flokki ber fyrst að telja tímaritin Kodomo no Tomo (Vinur barnsins), Kodomo no Kuni (Barnalandið) og Yonen Kurabu (Krakkaklúbburinn) sem voru stöndug tímarit með

63 Nokkur af kapólsku mánaðartímaritunum eru einnig í Nonnasafni Landsbókasafns en engin af dagblöðunum, að undanskildu dreifibréfinu með ensku greininni í The Japan Advertiser. 
margra ára sögu og umfangsmikla dreifingu. Sem dæmi má nefna að á opinberri heimasî́u Borgarbókasafnsins í Tókýó eru fyrstu tvö tímaritin nefnd sem dæmi um vỉlesin tímarit fyrir börn á Meiji- og Taisho-tímabilinu (1868-1925) sem varðveitt eru á skjaladeild bókasafnsins. ${ }^{64}$ Kodomo no Tomo hóf göngu sína árið 1914 og var áhrifamikið á heimilum menntafólks vegna framsækinnar stefnu í uppeldismálum. Mikið var lagt upp úr pví að fá bekkta myndlistarmenn til að skreyta tímaritið og sköpunargáfa lesendanna fékk einnig að njóta sín. ${ }^{65}$ Í blaðinu birtist stutt endurminning frá Íslandi eftir Jón í sérstöku pemahefti um jólahátíðina. Tímaritinu fylgdi einnig krakkadagblað par sem hnattferð Jóns er gerð góð skil í heilsî́ugrein. Kodomo no Kuni var einnig bekkt fyrir listrænt gildi, pótti framsækið fyrir nútímalega hönnun og breitt menningarlegt efnisval sem spannaði bæði ævintýri, myndasögur, söngtexta og ýmsa pætti sem gátu komið að gagni við menntun barna. Í Kodomo no Kuni birtist grein eftir Jón par sem hann segir frá kynnum sínum af japönskum börnum.

Mikilvægi pessara birtinga felst fyrst og fremst í pví að Jón og Nonnabækurnar fengu dýrmæta kynningu í tímaritum sem nutu mikillar virðingar; náðu til allra landsmanna og teygðu sig langt út fyrir hið fámenna samfélag kapólskra og annarra kristinna í Japan. Óhætt er að fullyrða að vinur Jóns, hinn ,japanski H. C. Andersen“, hafi haft einhverja milligöngu um að koma Jóni á framfæri en japanskar heimildir sýna að hann var talinn einn fremsti sérfræðingur landsins í uppeldisfræðum barna og barnabókmenntum.

\section{Fagtímarit um barnabókmenntir og menntun barna: Menntamaðurinn}

Annar mikilvægur vettvangur fyrir umfjöllun um Jón og verk hans eru fagtímarit rithöfunda og sérfræðinga sem unnu með bókmenntir,

64 https://www.library.metro.tokyo.lg.jp/collection/features/digital_showcase/005/index.html

65 Sjá opinbera heimasíðu Borgarbókasafnsins í Tókýó, https://www.library.metro.tokyo.lg.jp/collection/features/digital_showcase/005/09/

Hið pekkta barnatímarit Shonen Kurabu (Krakkaklúbburinn) sem hafði mikla dreifingu um allt land birti einnig söguna um Nonna og Manna (líklega í styttri útgáfu) með nýjum myndskreytingum. 
menntun og barnauppeldi. Ætla má að vinur Jóns, Fukuo Kishibe, hafi einnig hér gegnt lykilhlutverki pegar kom að pví að kynna Jón fyrir pekktustu barnabókahöfundum og menntasérfræðingum landsins. Greinar birtust um Jón í m.a. fagtímaritinu Dowa Kenkyu (Rannsóknir á ævintýrum) ${ }^{66}$ og hann tók pátt í faglegri umræðu um barnabókmenntir en Kishibe var pekktur fyrir að próa og innleiða kennslufræði sem fól í sér að nýta ekki aðeins ævintýri heldur einnig tónlist og dans í tengslum við menntun barna. Dowa Kenkyu greinir frá pví að haldið hafi verið málping í menningarhúsi Sophiaháskólans Jóni til heiðurs par sem ævintýri og barnabækur voru til umræðu. Fjörutíu pekktir sérfræðingar á pessu sviði tóku pátt í viðburðinum og pað fylgdi sögunni að gestirnir hafi beðið Jón um eiginhandaráritun eftir viðburðinn ${ }^{67}$. Раð er óhætt að álykta að kynni Jóns af fagfólki á sviði bókmennta, mennta og uppeldismála barna hafi enn frekar aukið áhugann á Jóni sem höfundi.

Á fjórða áratug síðustu aldar kviknaði áhugi japanskra stjórnvalda á pví að nýta aðferðafræði og frásagnartækni ævintýra til að innræta börnum pjóðernisleg gildi og föðurlandsást. Kishibe var pá einn af peim sérfræðingum um menntun barna sem var virkjaður til að nýta pekkingu sína og reynslu í págu japanska keisaraveldisins, enda leiðandi sérfræðingur á pessu sviði. ${ }^{68}$ Barnatímaritin frá pessum tíma sýna að t.a.m. myndskreyttar sögur af dugnaði og hugrekki japönsku hermannanna pótti sjálfsagt lesefni fyrir börn. Ríkið stýrði pegar öllu kennsluefni fyrir börn í gegnum algjörlega miðstýrt menntakerfi, en á strîđstímum pótti sjálfsagt og nauðsynlegt að seilast einnig inn í frítíma og inn á heimili barna í gegnum ævintýri og barnabókmenntir. Árið 1939 var Kishibe kominn í forustuhlutverk við að virkja höfunda barnabóka til að skrifa „uppbyggilegri sögur“, sem og að tengja betur sagnahöfunda og kennarastéttina til að betur mætti ala upp góða pegna í anda sannrar föðurlandsástar. Tilfelli Kishibe er engan veginn einstakt heldur sýnir pað glöggt hve langt ríkið gekk

66 Umfjöllun um Jón og verk hans er tî̉ust í Dowa Kenkyu en einnig birtist ítarleg grein um Jón t.a.m. í fagtímaritinu Kodomo no Kyoyo (Menntun barna). Skv. japanska akademíska leitargrunninum CiNii kom Dowa Kenkyu út á árunum 1922-1941. Greinarhöfundi hefur ekki tekist að finna upplýsingar um upplag/dreifingu en eintök eru varðveitt á tugum háskólabókasafna um allt Japan, sér í lagi við kennaraháskóla. Tímaritið fjallaði á breiðum grundvelli um ævintýri og sögur/bækur fyrir börn í tengslum við uppeldis- og kennslufræði.

67 Uchiyama, Kendo, „Hokkyoku no dowaka ...“

68 Sjá m.a. „Notes on Art and Literature,“, bls. 8. 
á öllum sviðum til að rækta pjóðarhollustu, ala upp góða pegna og móta samfélagið. Hvernig skyldu Nonnabækurnar hafa rímað við pennan veruleika hernaðar- og keisaraveldis? Fátt bendir til að japönsku pýðingarnar á Nonnabókunum og öðrum textum eftir Nonna hafi verið ritskoðaðar, og ætla má að boðskapurinn um hugrekki, prautseigju og ást á sínum nánustu, líkt og birtist í Nonnasögunum, hafi pótt æskilegt veganesti fyrir japanska æsku (verðandi hermenn), jafnvel pótt bræðurnir hafi heitið á „erlendan guð“ pegar líf peirra lá við. Nálægð Jóns og Nonna við hin pjóðernislegu verkefni sjást m.a. glöggt í tímaritinu Dowa Kenkyu ${ }^{69}$, par sem efnisyfirlitið báðum megin við greinina um Jón fjallar um hvernig nýta megi ævintýri til að efla pjóðernishyggju.

\section{Nonnabækurnar sjálfar}

Að lokum er ekki úr vegi að nefna hvað japönsku útgáfurnar á Nonnabókunum sjálfum segja okkur um viðtökur verkanna í Japan, bæði Nonnabókunum premur sem gefnar voru út í tengslum við Japansdvöl Jóns árin 1937-1938 og fleiri titlum sem fylgdu í kjölfarið. ${ }^{70}$ Eins og áđur sagði var Pjóðverjinn Rupert Eberle lykilmaður pegar kom að útgáfu fyrstu Nonnabókanna í Japan. Eberle hafði áður unnið fyrir Herder, kristilega forlagið sem gaf út Nonnabækurnar í Evrópu, og sambönd hans í japönskum útgáfuiðnaði, sem og reynsla af bókaútgáfu hefur komið sér vel. Fyrstu bækurnar komu út hjá litlum forlögum sem jafnvel virðast stofnuð sérstaklega í kringum bækur Jóns. Рað sem lengi hefur vakið furðu og forvitni greinarhöfundar er hvers vegna Nonnabækurnar voru ekki gefnar út hjá stærra eða pekktara forlagi. Eins og komið hefur fram tókst fádæma vel að kynna Jón sem heimspekktan höfund og áhuginn á Jóni hlýtur að hafa farið fram úr væntingum. Hefði ekki sæmt „H. C. Andersen samtímans“ og „Mark Twain Evrópu“ að bækurnar væru gefnar út

69 Sjá sér í lagi árgang 17 blað 10 frá 1937, sem virðist sérstakt pemahefti um petta efni.

70 Sjá titlana sem liggja til grundvallar fyrstu premur Nonnabókunum á japönsku í Pater Jón Sveinsson: Nonni eftir Gunnar F. Guðmundsson, bls. 491, nr. 103. Рað er snúið að átta sig á japönsku bókatitlunum par sem peir eru oft frjálslega pýddir og hvergi er hægt að nálgast allar japönsku útgáfurnar af Nonnabókunum á einum stað. Skv. japönsku Nonnasýningunni frá 2008 voru til alls 15 bækur á japönsku með sögum eftir Jón Sveinsson. Pær voru ekki nafngreindar en líklega eru bæði endurútgáfur og safnrit meðtalin. 
hjá einu af stóru forlögunum? Pegar býðingin á Sjálfstceðu fólki eftir Halldór Laxness kom út í Japan tveimur áratugum síoar var útgefandinn Kodansha, eitt stærsta og öflugasta bókaforlag Japans og a.m.k. ein af seinni útgáfum á Nonnabókunum kom einmitt út hjá Kodansha. En misræmið milli frægðar Nonna í Japan og algjört nafnleysi útgefendanna á fyrstu bókunum vekur óneitanlega upp spurningar. Fjárhagserfiðleikar jesúítatrúboðsins, sem mátti ekki við neinu tapi, og vandlega skipulögð kynningarherferðin gefa vísbendingar um að ekki hafi verið tilviljun hvernig Jesúítareglan spilaði úr pví trompi sem heimsókn Jóns var. Var kannski ekki áhugi hjá stóru forlögunum á kristnum bókmenntum um pessar mundir? Var fjárhagslega hagkvæmara fyrir gestgjafa Jóns að standa sjálfir að útgáfu bókanna? Var Herder-tengingin í gegnum Eberle kannski svo augljós að önnur forlög komu ekki til greina eða var of seinlegt að semja við stóru forlögin? Pví miður eru engin svör tiltæk við pessum spurningum að svo stöddu.

Annað lykilatriði sem hefði getað gefið betri mynd af viðtökum Nonnabókanna í Japan eru sölutölur, eða jafnvel útlán á almenningsbókasöfnum, sem voru í miklum vexti. Pví miður hefur Nonnasafn á Íslandi ekki að geyma yfirlit yfir sölu Nonnabókanna á heimsvísu eða áreiðanlegar tölur um bóksölu í einstökum löndum. Ekki er vitað hvernig bækurnar seldust í Japan, eða hvort gróði eða tap var á útgáfu peirra. Hitt er víst að vandað var til verka, a.m.k. á peim árum sem pessi rannsókn nær yfir. Kápurnar á fyrstu premur bókunum voru hannaðar „í stíl“ og í formála eftir Kishibe í fyrstu bókinni sem kom út er býðanda sérstaklega hrósað fyrir vönduð vinnubrögð og frábær gæði japanska textans sem komi hreinleika frumtextans til skila. ${ }^{71}$ Tveimur áratugum síđar býddi Shizuka Yamamuro, sem var aðalbýðandi á Sjálfstceðu fólki á japönsku, ${ }^{72}$ Nonnabókina Nonni shōnen no daikōkai pannig að áfram var hugað að gæðum textans. Önnur vísbending um góðar viðtökur verkanna er að Nonnabækurnar voru gefnar út með nokkuð jöfnu millibili yfir lengri tíma. Á Nonnasýningunni í Japan árið 2008 voru kynntar 15 bækur með textum

71 Jón Sveinsson, Nonni kyōdai no bōken [Ævintýri Nonnabræðranna], formáli.

72 Sjá heimasíðu Gljúfrasteins, http://gljufrasteinn.is/is/halldor_laxness/thydingar/japanska/. Yamamuro var mikilvirkur pýðandi og hann býddi alls fjórar Nonnabækur á japönsku. Eftir hann liggja fjölmörg skrif um norrænar bókmenntir og býðingar á verkum helstu höfunda Norðurlanda. 
um eða eftir Jón Sveinsson sem höfðu verið gefnar út par í landi, pær fyrstu meðan Jón dvaldi í Japan árið 1937 og sú nýjasta árið 2008. ${ }^{73}$ Pað segir einnig sína sögu að fyrstu Japanirnir sem komu til náms á Íslandi á 6. og 7. áratugnum nefndu Nonna sem eitt af pví fyrsta og jafnvel pað eina sem pau vissu um Ísland pegar pau voru að alast upp í Japan. ${ }^{74}$ Pannig að Jón Sveinsson hefur sannarlega sáo fræi Íslandsáhuga í Japan.

\section{Lokaorð - helstu niðurstöður}

Oft hefur verið haft á orði að rithöfundurinn Jón Sveinsson sé einn besti sendiherra sem Ísland hefur átt. Pað bregst ekki að Jón er kenndur við Ísland og hann var óspar á faguryrði um ævintýraeyjuna Ísland en á sama tíma er hann hámenntaður heimsborgari og heimshornaflakkari, hefur búið í helstu menningarborgum Evrópu og hefur tungur stórvelda á valdi sínu, m.a. býsku, frönsku og ensku. Jón var maður margra heima og fjölhæfur pannig að hann reyndist góður sendiherra fyrir fleiri en Íslendinga. Petta sannaðist í Japansferð Jóns par sem hann sjálfur - og umfangsmikil umfjöllum um hann - náði til ólíkra hópa samfélagsins. Gestgjafarnir við Sophiaháskólann í Tókýó sáu mikil tækifæri í Jóni og með pennan öfluga liðsauka gátu peir sinnt trúboðshlutverki sínu betur en fyrr og kynnt háskólann og menntastarf sitt í leiðinni, án pess að of mikill trúarbragur væri á kynningarstarfinu pegar slíkt átti illa við. Sá eiginleiki Jóns að höfða sterkt til ólíkra hópa á öllum aldri gagnaðist trúbræðrum Jóns í Jésúítareglunni svo um munaði. Рað er pví ekki að undra að Hermann Heuvers, forseti Sophia-háskólans og gestgjafi Jóns í Japan, hafi kosið að Jón dveldist lengur eða settist jafnvel að í Japan, eins og fram kemur í ævisögu Jóns eftir Gunnar F. Guðmundsson. ${ }^{75}$

Pegar viðtökur Jóns í Japan eru skoðaðar er tvennt sem ber að hafa í huga. Annars vegar pær sérstæðu aðstæður sem uppi voru í jap-

73 Petta kemur fram í upplýsingum á sýningarspjöldum í Nonnasýningunni Seinni ferð̀ Nonna til Japans. Aðeins fáir titlar eru nafngreindir en hér eru væntanlega meðtaldar ýmsar útgáfur af Nonnabókunum, t.a.m. endurútgáfur og endurbýðingar, sem og sögur eftir Jón í safnritum.

74 Kristín Ingvarsdóttir, „Samskipti Íslands og Japans eftir síðari heimsstyrjöld ...”, bls. 525-526.

75 Gunnar F. Guðmundsson, Pater Jón Sveinsson: Nonni, bls. 395. 
önsku samfélagi á meðan á Japansdvölinni stóð og hvernig rithöfundurinn Jón Sveinsson, Nonnabækurnar og viðhorf Jóns pössuðu (eða pössuðu ekki) inn í pann veruleika. Hins vegar vekur athygli hve gríðarlega mikil umfjöllun var um dvöl Jóns í Japan og hve víða hann kom við. Pessar heimildir eru vitnisburður um margpætta sýn Japana á Jón og verk hans. Fjölbreyttur birtingarvettvangur segir einnig sína sögu.

Pað er augljóst að mikil kynningarherð fór af stað við komu Jóns til landsins. Íslenski bakgrunnurinn vakti hvarvetna forvitni og athygli en pýskur bakgrunnur Jóns hefur væntanlega heldur ekki spillt fyrir af ýmsum ástæðum. Pjóðverjar og Japanir gengu í bandalag sî̉la árs 1936 en Japanir höfðu pá einangrast mjög á alpjóðavettvangi og áttu fáar aðrar vinapjóðir. Sophia-háskólinn var rekinn af býska umdæmi Jesúítareglunnar og miklar býskar áherslur voru í starfi háskólans. Kristni og kristniboð mætti nokkurri tortryggni í Japan og allt bendir til pess að Sophia-háskólinn hafi jafnframt purft að laga sig mjög eindregið að kröfum stjórnvalda um menntun og innrætingu í anda ströngustu pjóðernishyggju Japana eftir Yasukuniatvikið árið 1932, sem tefldi tilvist háskólans í tvísýnu. Á hinn bóginn höfðu Japanir lengi borið virðingu fyrir Pýskalandi og pýskri menningu, pannig að tenging við pýskan jesúítaskóla var bæði kostur og galli.

Fyrir Jóni var Japan sannkallað drauma- og ævintýraland og í ljósi ofangreindra aðstæðna er mjög ólíklegt að hann hafi heyrt miklar gagnrýnisraddir gagnvart Japönum meðal gestgjafa sinna eða í nánasta tengslaneti. Pá hafði rómuð gestrisni Japana sitt að segja. Dvölin í Japan styrkti pví pá jákvæðu mynd sem Jón hafði af Japan fyrir komuna til landsins og í skrifum sínum og dagbókarfærslum verður honum tîðrætt um hve kurteisir, gáfaðir, vinnusamir og hugrakkir Japanir séu. Japanskur útgáfuiðnaður var gegnsýrður af ritskoðun pegar leið á fjórða áratug sídustu aldar en fátt bendir til pess að sögur og greinaskrif Jóns hafi orðið fyrir ritskoðun stjórnvalda. Jón er mjög hlyntur Japönum í öllum skrifum sínum og skoðanir hans og umburðarlyndi gagnvart t.a.m. útpenslu Japans í Kína markast mjög af japönskum áróðri og ríkjandi skoðunum pessara ára. ${ }^{76} \mathrm{~Pa}$ er

76 Gunnar F. Guðmundsson, Pater Jón Sveinsson: Nonni, bls. 396-399. Sjá einnig dagbækur Jóns frá Japansdvölinni. 
pó ljóst að hrifning Jóns á Japan og Japönum byggist fyrst og fremst á persónulegri upplifun: pví framandi ævintýri sem hann lifir í Japan og pví fólki sem hann kynnist. Jón skrifaði um Japan af einlægri hrifningu og innlifun, og skrifin féllu eðlilega í kramið hjá Japönum.

Pegar umfangið á umfjöllun um Jón í japönskum blöðum og tímaritum er skoðað er freistandi að draga pá ályktun að viðtökurnar hljóti að hafa verið vonum framar. Umfjöllunin birtist ekki bara í mörgum miðlum heldur einnig í „réttu“ miðlunum sem voru áhrifamiklir hver á sínu sviði og pað er augljóst að ímynd Jóns var löguð að ólíkum miðlum og markhópum. Pannig var Jón kynntur sem heimspekktur rithöfundur á heimsreisu gagnvart alpjóðlega samfélaginu í Tókýó í stærstu enskumælandi dagblöðum landsins. Î japanska stórblaðinu Asahi Shimbun fær frásagnargáfa Jóns að njóta sín og hann skrifar áhugaverða og gamansama pistlaröð um upplifun sína af japönsku samfélagi. Sannast par hið fornkveðna að glöggt er gests augað. Í kabólskum og kristnum ritum var lögð áhersla á Jón sem fyrirmynd í trúmálum og hvernig trúin hafði hjálpað honum að yfirstíga erfiðleika á lífsleiðinni. Jafnframt var lögð áhersla á Nonnabækurnar, enda var hér um mikilvægan markhóp að ræða pegar kom að sölu bókanna enda pótt samfélag kapólskra í Japan væri ekki fjölmennt. Efni frá Jóni birtist einnig á ólíku formi í virtum tímaritum fyrir börn, sem voru bæði vî̉lesin og pekkt fyrir nútímalegar áherslur í uppeldismálum og listrænt gildi. Af pessu má sjá að skrif Jóns náđu langt út fyrir hið prönga samfélag kapólskra manna. Með hliðsjón af markhópi tímaritanna má ætla að skrif hans hafi borist inn á heimili fjölmargra sem meira máttu sín vítt og breitt um Japan. Greinarhöfundur hefur enn sem komið er ekki fundið umfjöllun um Jón í almennum tímaritum um bókmenntir og menntamál frá pessum tíma en greinar birtust í tímaritum á borð við Dowa Kenkyu sem sérstaklega fjallaði um börn og barnauppeldi. Hér er einnig um mikilvægan markhóp að ræða par sem bæði aðstandendur og lesendur blaðanna voru áhrifafólk á sviði menntunar og barnamenningar.

Ef marka má af peim tugum birtinga um Jón frá peim tíma sem hann dvaldist í Japan, og liggja til grundvallar pessari umfjöllun, bendir allt til pess að Japansför Jóns hafi verið mikil sigurför. Pótt mikið sé til af efni eru pó tvær ópekktar breytur í jöfnunni sem hefði verið áhugavert að pekkja betur. Í fyrsta lagi er sem stendur ekkert 
vitað hvernig Nonnabækurnar seldust. Stór markaður var fyrir bókaútgáfu í Japan á millistrîđsárunum en samkeppnin hefur vafalítið einnig verið mikil. Jafnframt voru almenningsbókasöfn að ryðja sér til rúms pannig að sölutölur og útbreiðsla hafa ekki endilega alltaf farið saman. Í öðru lagi vekur spurningar hvers vegna Nonnabækurnar voru gefnar út hjá lítt pekktum forlögum. Hefði ekki verið eðlilegt að bækur pekkts og vinsæls höfundar eins og Jóns væru gefnar út hjá stöndugu og virtu forlagi? Ekki fást svör við pessum spurningum að svo stöddu en hitt er víst að alls komu út á japönsku 15 bækur sem innihéldu sögur eftir Jón (p.m.t. endurútgáfur) á 70 ára tímabili, síðast árið 2008. Рað bendir til pess að Jón Sveinsson og Nonnabækurnar hafi átt dyggan aðdáenda- og lesendahóp í Japan í nokkrar kynslóðir. 


\section{Evintýraeyjurnar Japan og Ísland: \\ Um Japansdvöl Nonna, 1937-1938}

Seint á rithöfundarferli Jóns Sveinssonar, Nonna, rættist draumur hans um að ferðast til Japans og hvergi fundust Jóni viðtökurnar betri en einmitt par. Jón var pó pekktur víða um lönd og einn víðförlasti Íslendingur síns tíma, enda höfðu barnabækur hans verið pýddar á um 30 tungumál. Jón kom til Japans vorið 1937 og dvaldist í eitt ár við hinn pekkta Sophia-háskóla í Tókýó, sem rekinn var af trúbræðrum hans í Jesúítareglunni. Markmiðið með pessari grein er að varpa ljósi á Japansdvöl Jóns á grundvelli rannsóknar á japönskum heimildum frá peim tíma sem Jón dvaldist í landinu. Leitast verður við að svara hvar og með hvaða hætti fjallað var um rithöfundinn Jón og verk hans í japönskum dagblöðum og tímaritum. Dvöl Jóns í Japan vakti mikla athygli og umfjöllun pví bæði tíd og umfangsmikil. Til grundvallar umfjölluninni liggja heimildir sem greinarhöfundur hefur mestmegnis aflað í japönskum skjalasöfnum og gagnagrunnum. Með pví að rannsaka pessar heimildir bætist nýtt sjónarhorn við fyrri rannsóknir á Japansvöl Jóns. Jafnframt verður lögð áhersla á að varpa ljósi á pær pjóðfélags- og trúarhræringar sem ruddu sér til rúms í Japan á fyrri hluta sîđustu aldar og hafa vafalítið haft áhrif á pær viðtökur sem höfundurinn og verk hans hlutu par í landi. Vikið verður að hlutverki og stöðu Sophia-háskólans í japönsku samfélagi, sem og flókna stöðu kristinnar kirkju og jesúíta í Japan á áratugunum fyrir seinni heimsstyrjöld, en pau markast af uppgangi heimsvaldastefnu, pjóðernishyggju, ríkisrekinni trúarstefnu og stríosrekstri á meginlandi Asíu.

Lykilorł: Jón Sveinsson - Nonni, Japan, viðtökur (fjölmiðlaumfjöllun), ferðasögur, trúarbrögð 


\section{Japan and Iceland: Adventure Isles Nonni's stay in Japan 1937-1938}

Late in his career as an author, Jón Sveinsson, Nonni, realised his dream of visiting Japan and nowhere did he feel that he had met with a better reception than in Japan. This despite the fact that Jón was among the best known and most widely travelled Icelanders of his time, as his popular children's books had been translated into around 30 languages. He arrived in the spring of 1937, to spend a year at the well-known Sophia University, run by his fellow Jesuits in Tokyo. The present article aims to cast light on Jón's stay in Japan and where and how the writer and his works were discussed in contemporary Japanese newspapers and magazines. As Jón Sveinsson's stay in Japan attracted a great deal of attention, media reports were both frequent and extensive. This article is based on sources gathered by the author from mainly Japanese archives and databases. These sources add a new perspective to previous research conducted on Jón Sveinsson's Japan visit. Emphasis is also placed on the significance of the social and religious changes gaining prominence in Japan in the first half of the last century, which undoubtedly influenced the reception of the author and his work. The role and position of Sophia University in Japanese society is also examined, together with the complicated status of Christianity and the Jesuits in Japan in the years preceding World War II, which were characterised by ascending imperialism, nationalism, state Shinto and armed aggression on the Asian continent.

Keywords: Jón Sveinsson - Nonni, Japan, reception (media coverage), travel literature, religion 


\section{HEIMILDIR Á ÍSLENSKU OG ENSKU}

Anderson, Emily, Christianity and Imperialism in Modern Japan: Empire for God. London, New Delhi, New York, Sidney: Bloomsbury, 2016.

„Annual Reception Held at Tokyo Club“, The Japan Times, 19. mars 1938.

Bergpóra Jónsdóttir, „Nonni í Japan: Japanska krónprinsessan meðal aðdáenda“, Morgunbladid 24. nóvember 2009, bls. 27.

Bix, Herbert P., Hirobito and the Making of Modern Japan, New York: Harper-Collins Publishers, 2000.

„Child Story Writers Plan Nara Meeting“, The Japan Times, 26. desember 1939, bls. 2.

de Bary, William T., Gluck, Carol og Tiedemann, Arthur E., Sources of Japanese Tradition: Volume Two: 1600-2000; Part Two: 1868 to 2000, New York: Colombia University Press, 2006.

Garon, Sheldon M., „State and Religion in Imperial Japan, 1912-1945“, The Journal of Japanese Studies, 12 (2), 1986, bls. 273-302.

Gordon, Andrew, A Modern History of Japan: From Tokugawa Times to the Present, 4. útgáfa, Oxford: Oxford University Press, 2020.

Gunnar F. Guðmundsson, Pater Jón Sveinsson: Nonni. Reykjavík: Opna, 2012.

Hardacre, Helen, Shintō and the State, 1868-1988, New Jersey, Chichester: Princeton University Press, 1989.

Helga Birgisdóttir, „Af hverju urðu Nonna- og Mannabækurnar svona vinsælar?“, Vísindavefurinn, 2013, https://www.visindavefur.is/svar.php?id=58420 [sótt 10. október 2020].

Iriye, Akira, Japan E The Wider World: From the Mid-Nineteenth Century to the Present, London, New York: Routledge, 1997.

Jansen, Marius B., The Making of Modern Japan, Cambridge, Mass.: The Belknap Press of Harvard University Press, 2000.

„Japanska“, Gljúfrasteinn, http:/gljufrasteinn.is/is/halldor_laxness/thydingar/japanska/ [sótt 10. júlí 2020].

Jón Hjaltason, Nonni og Nonnabús, Akureyri: Bókaútgáfan Hólar, 1993.

Jón Sveinsson, Ferð Nonna umbverfis Jörðina, Sídari hluti: Nonni i Japan, pýð. Freysteinn Gunnarsson, 2. útgáfa, Reykjavík: Ísafoldarprentsmiðja, 1971.

Kawana, Sari, „Reading Beyond the Lines: Young Readers and Wartime Japanese Literature“, Book History 13, 2010, bls. 154-184.

Kristín Ingvarsdóttir, ,„,Frá Sóleyjum“: Upphaf samskipta Íslendinga og Japana 1904-1942“, Skirnir 191 (1), 2017, bls. 80-114.

Kristín Ingvarsdóttir, „Samskipti Íslands og Japans eftir sîđari heimsstyrjöld: Stjórnmálasamband í 60 ár“", Skírnir 191 (2), 2017, bls. 501-544.

„Mr. Kishibe’s Birthday“, The Japan Times, 17. febrúar 1933, bls. 8.

„Nonni í Ameríku“, pjódviljinn, 29. nóvember 1995, bls. 6.

„Nonni í Japan“, Lesbók Morgunbladsins, 7. nóvember 1937, bls. 350.

„Notes on Art and Literature,“ The Japan Times, 16. apríl 1933, bls. 8.

„Seinni ferð Nonna til Japans“, Fréttablaðið, 19. september 2008, bls. 24. 
Silja Aðalsteinsdóttir, Íslenskar barnabaekur 1780-1979, Reykjavík: Mál og Menning, 1981.

Skapti Hallgrímsson, „Enn er Nonni í sviðsljósinu í Japan“, Morgunblađið 14. október 2008, bls. 34 .

„The 1932 Yasukuni Shrine Incident“, Sophia University, 2013, https://www.sophia. ac.jp/eng/aboutsophia/history/u9gsah00000007pn-att/websophiaE40.pdf [sótt 9. júlí 2020].

„The Launching of a Small Residence Hall of Learning“, Sophia University, https:/ www.sophia.ac.jp/eng/aboutsophia/history/u9gsah00000007pn-att/websophia_ e2.pdf [sótt 9. júlí 2020].

Tokuji, Saisho. „Art-Music-Letters“, The Japan Times, 23. mars 1937, bls. 8.

„Xavier and Sophia University“, Sophia University, https://www.sophia.ac.jp/eng/ aboutsophia/history/u9gsah00000007pn-att/websophia37E.pdf [sótt 10. júlí 2020].

\section{HEIMILDIR Á JAPÖNSKU ${ }^{77}$}

„Bikkuri shita Nonni kyōdai rokuji ima Anderusen no dōwa“, [Nonnasögurnar í útvarpinu kl. 6, Andersen okkar tíma], Tokyo Asabi Shimbun, 6. Maí 1937, bls. 7. "Janken no hanashi Aisurando de dairyūkō" [Sagan um vinsældir janken á Íslandi], Tokyo Asahi Shimbun, 5. júní 1938, bls. 6.

Jón Sveinsson, „Aisurando no kurisumasu [Jól á Íslandi], Kodomo no tomo, 24 (12), 1937, blaðsíðutal ekki gefið upp.

Jón Sveinsson, Appare Nonni [Bravó Nonni], pýd. Tamotsu Itō, Tókýó: Enderure shoten, 1948.

Jón Sveinsson, „Kyorokyoro shite mujaki na Nippon no kodomo-tachi“ [Saklausu japönsku börnin lítandi í kringum sig], Kodomo no kuni, 16 (9), Tókýó: Tokyosha, 1937 , bls. 25.

Jón Sveinsson, „Nippon no inshō (1)“ [Upplifun mín af Japan (1)], Tokyo Asabi Shimbun, 21. apríl 1937, bls. 7.

Jón Sveinsson, „Nippon no inshō (2)“ [Upplifun mín af Japan (2)], Tokyo Asabi Shimbun, 22. apríl 1937, bls. 7.

Jón Sveinsson, „Nippon no inshō (3)“ [Upplifun mín af Japan (3)], Tokyo Asabi Shimbun, 23. apríl 1937, bls. 7.

Jón Sveinsson, Nonni kyōdai no bōken [Ævintýri Nonnabræðranna], pýð. Kenji Uezawa, Tókýó: Kōseikaku, 1937.

Jón Sveinsson, Nonni shōnen no daikōkai [Stórsigling drengsins Nonna], pýð. Shizuka Yamamuro, Tókýó: Hōbunkan, 1957.

Jón Sveinsson, Nonni to kōri no okuni [Nonni og íslandið], býð. Tamotsu Itō, Tókýó: Enderure shoten, 1948.

Jón Sveinsson, Nonni to Manni [Nonni og Manni], pýd. Kenji Uezawa, Yōnen

77 Hér eru fyrst og fremst taldar upp pær greinar og birtingar sem eru beint nefndar eða vísað í. Greinarnar sem nýttar voru fyrir rannsóknina eru alls um 70 talsins. 
kurabu 15 (12), Tókýó: Dainippon-yūbenkaikōdansha, 1940, bls. 125-136.

Jón Sveinsson, „Owakare no kotoba suki na Nippon de kurashita ichinen“ [Kveðjuorð til míns ástkæra Japans sem ég dvaldi í um eins árs skeið], Tokyo Asahi Shimbun, 20. febrúar 1938, bls. 6.

Jón Sveinsson, Sukiparon he no kurisumasu no hōmon [Jólaheimsókn í Skipalón], pýd. Suematsu Daigūji, Tókýó: Ōtorisha, 1974.

Jón Sveinsson, „Watashi no otomodachi - kawaii minasan he dōwaka Suvenson“ [Til vina minna, allra fallegu barnanna í Japan - frá barnabókahöfundinum Sveinssyni], Tokyo Asahi Shimbun, 25. mars 1937, bls. 4.

„Kita no kuni Aisurando kara kita dōwa no ojiisan to ohanashi suru“ [Samtal við gamla barnabókahöfundinn sem kom frá Íslandi], Kodomo no tomo furoku seikatsushimbun, 1. maí 1937, blaðsíðutal ekki gefið upp.

„Kodomo no kuni“, Tokyo Metropolitan Library, https://www.library.metro.tokyo. lg.jp/collection/features/digital_showcase/005/10/index.html [sótt 9. júlí 2020].

„Kodomo no tomo“, Tokyo Metropolitan Library, https://www.library.metro.tokyo. lg.jp/collection/features/digital_showcase/005/09/index.html [sótt 9. júlí 20201.

Okamoto Ippei, „Suvenson ō“ [Hinn mikli Sveinsson], Tokyo Asabi Shimbun, 1. ágúst 1937 , bls. 9.

„Otogi no okuni kara hachijūō Suvenson shi“ [Hinn áttræði hr. Sveinsson sem kom frá ævintýralandinu], Tokyo Asabi Shimbun, 19. mars 1937, bls. 11.

Uchiyama, Kendo, „Hokkyoku no dowaka Suvenson shi“ [Ævintrýahöfundurinn hr. Sveinson frá Norðurslóðum], Dowa Kenkyu, 17 (6), 1937.

\section{ÓBIRTAR HEIMILDir}

Nonnasafn Landsbókasafns Íslands, Háskólabókasafn

Bréfasafn.

Dagbækur II. bindi.

Myndaalbúm, Japan.

Ritgerðir skrifaðar í Tókýó, Japan, 1937.

Sérprentanir og úrtök, 1935-1951.

Ýmis gögn E-D.

Ýmis gögn, laus mappa ... Japan.

\section{VIĐTÖL OG TÖLVUPÓSTSAMSKIPTI}

Fulltrúi Jesúítareglunnar við Sophia-háskólann í Tókýó (maí 2018 og október 2019).

Brynhildur Pétursdóttir, fyrrverandi safnstjóri Nonnahúss og einn af aðalskipuleggjendum Nonnasýningar í Japan 2008 (vor 2018 og sumar 2020). 
Motokatsu Watanabe, fyrrverandi sendifulltrúi japanska sendiráđsins á Íslandi, einn af aðalskipuleggjendum Nonnasýningar í Japan 2008 (maí 2018).

\section{ANNAĐ PRENTAĐ EFNI}

Geppert, Theodor, The Early Years of Sophia University, Tókýó: [óútgefið handrit], 1993.

Nonnasýningin Seinni ferð Nonna til Japans frá 2008, Sýningarspjöld (megintexti). (J.ノンニの70年後の再訪日 [Nonni no nanajūnengo no saihōnichi]. 